\title{
Response of Head Cabbage (Brassica Oleracea L.) to Different Rates of Inorganic Nitrogen Fertilizer and Farmyard Manure at Bore, Southern Oromia, Ethiopia
}

\author{
Solomon Teshome ${ }^{1^{*}} \quad$ Tamado Tana $^{2} \quad$ Wassu Mohammed $^{2}$ \\ 1.Oromia Agricultural Research Institute Bore Agricultural Research Center, Bore, Ethiopia \\ 2.Department of Plant Science, Haramaya University, Haramaya, Ethiopia
}

\begin{abstract}
Cabbage (Brassica oleracea L.) is the second most important vegetable crop in Ethiopia in area coverage as well as level of production next to red pepper. However, yield of the crop is often constrained by low and imbalanced nutrient supply. This study was conducted at the Bore Agricultural Research Center (BoARC) during the main cropping season to assess the response of $\mathrm{N}$ and FYM on growth and yield of cabbage. The treatments consisted of factorial combinations of five levels of $\mathrm{N}\left(0,59,119,235\right.$ and $294 \mathrm{~kg} \mathrm{~N}$ ha $\left.^{-1}\right)$ and four levels of FYM $(0,3,6$ and $10 \mathrm{tha}^{-1}$ ) and were laid out in RCBD with three replications. The ANOVA results showed that interaction effect of $\mathrm{N}$ and $\mathrm{FYM}$ significantly $(\mathrm{P}<0.001)$ difference on plant height, number of expanded leaves, days to head initiation, days to $90 \%$ maturity, head height, head diameter, untrimmed head weight, trimmed head weight, yield with and without wrapper and biomass of yield. There was a Significance differences between the mean plant heights $(43.2 \mathrm{~cm})$ of head cabbage observed versus FYM of $\left(10 \mathrm{t} \mathrm{ha}^{-1}\right)$ with each level of $\mathrm{N}\left(235 \mathrm{~kg} \mathrm{ha}^{-1}\right)$ for plant height. However, the combined effect of highest N $\left(294 \mathrm{~kg} \mathrm{ha}^{-1}\right)$ and highest FYM $\left(10 \mathrm{t} \mathrm{ha}^{-1}\right) \mathrm{recorded}^{-3}$ maximum number of leaves (16.66), shortest days to head initiation (63.33) and early days to maturity (112). And also the interaction effect of both $\mathrm{N}$ and FYM (235 kg $+6 \mathrm{tha}-1)$, respectively was highly significantly $(\mathrm{P}<0.001)$ recorded highest head height $(18.14 \mathrm{~cm})$, highest head diameter $(17.03 \mathrm{~cm})$, highest untrimmed head weight $(2296.67 \mathrm{~g})$, highest trimmed head weight $(1766.67 \mathrm{~g})$, maximum $\left(107.47 \mathrm{t} \mathrm{ha}^{-1}\right)$ yield with wrapper head cabbage, highest head yield without wrapper $\left(72.36 \mathrm{t} \mathrm{ha}^{-1}\right)$ and maximum biomass yield $\left(107.47 \mathrm{t} \mathrm{ha}^{-1}\right)$ of head cabbage. There was an increasing trend in the yield without wrapper or marketable head yield parameter with the increasing in the rate till combined application of $235 \mathrm{~kg} \mathrm{~N} \mathrm{ha}^{-1}$ from UREA and $6 \mathrm{t} \mathrm{FYM} \mathrm{ha}{ }^{-1}$, but the yield declined above these combinations. Based on partial budget analysis the highest net benefit was obtained from treatment combinations of $235 \mathrm{~kg} \mathrm{~N}^{-1}$ with $6 \mathrm{t} \mathrm{ha}^{-1}$ with a marginal rate of return $2535.31 \%$. The most attractive rates for the producers with low cost of production and higher benefits in this case were treatment combination of $235 \mathrm{~kg} \mathrm{~N} \mathrm{ha}^{-1}$ with $6 \mathrm{t} \mathrm{ha}^{-1}$. Generally results of the study suggested that head cabbage responded well to the combined application of $\mathrm{N}$ and FYM and application of $235 \mathrm{~kg} \mathrm{~N} \mathrm{ha}^{-1}+6 \mathrm{t} \mathrm{FYM} \mathrm{ha}^{-1}$ can give optimum cabbage head yield in the study area.
\end{abstract}

Keywords: FYM, N, Thomas F1, Trimmed Head, Untrimmed Head, Yield with Wrapper, Yield without Wrapper

DOI: $10.7176 / \mathrm{JAAS} / 52-03$

\section{INTRODUCTION}

Cabbage belongs to the member of Brassicaceae family, genus Brassica and Brassica oleoracea L, the progenitor form of cabbage which is believed to have evolved in the Mediterranean area. It was introduced to China more than 2000 years ago, where the heading (Brassica oleoracea L) types were developed. They contain different amounts of nutrients with savoy type being more superior (Yamaguchi, 2003). Initially cabbage was used for medicinal purposes such as treatment for gout, stomach problems, headaches and deafness, while now it is mainly used as a fresh market crop and for processing. For processing, cabbage can be mixed with other vegetables or sold as stir-fry and for making sauerkraut (Pierce, 2007).

Cabbage is the second most important vegetable crop in Ethiopia both in area coverage as well as level of production next to red pepper, or Capsicum species (MoA, 2011). Vegetables accounted only about $1.43 \%$ of the area under all crops at national level. However, of the total estimated area under vegetables, $70.89 \%$ and $18.07 \%$ was under red peppers and head cabbage, respectively (CSA, 2012). In the Gudji Zone, head cabbage is widely cultivated; and the area (ha), production (tons), and yield (ton ha ${ }^{-1}$ ) of the crop in meher season of 2012/13 was 1703.77, 15678.3 and 9.2, respectively (CSA, 2012). In fact there is no evidenced information on the level of production and marketing of the head cabbage both in the study area and country. Head cabbage is an important cool season crop in highland parts of the zone including Bore. The productivity and market access were high in the area that transported up to the border of the country (Personal observation).

Head cabbage has short stem and a globular head of tightly overlapping green to purplish leaves. As far as their heads are concerned they are compact or loose. It is a biennial crop that is grown as an annual which takes 6-11weeks from planting to the end of the vegetative stage. Cabbage is a cool season crop which requires 
adequate availability of soil water and plant nutrients for optimum growth. It has a moderately high frost tolerance. It will grow at $7{ }^{\circ} \mathrm{C}$, but it does best from $15.5-18{ }^{0} \mathrm{C}$, above $27{ }^{0} \mathrm{C}$ the plants may bolt, causing the heads to split open (Ashworth, 2002). Cabbage seed germinate in about two weeks in soils with temperature as low as $10{ }^{\circ} \mathrm{C}$, which allows for early plantings in cooler regions (Smith, 1995). Depending on the variety, cabbage requires 60 to 100 days from sowing to reach market maturity. A well-drained sandy loam soil with good organic content and soil $\mathrm{pH}$ of between 6.0 and 6.5 is preferred (Yano et al., 1999).

High human and animal population densities in some areas in the highlands of Ethiopia like Gudji have surpassed land carrying capacities escalating environmental degradation. Ethiopia has the highest livestock Resource in Africa. The traditional balance between people, livestock and their habitat and the socio-economic systems is fast disappearing. Hence, achieving sustainable increases of agricultural production has been a priority problem of the country (Wakene et al., 2001).

In order to maintain and improve cabbage production, through agronomic practices some factors have to be considered. Use of integrated nutrient management and correct agricultural practices such as optimum application of nutrients has to be adhered for successful vegetable production (Bulluck, et al., 2002). Especially in an area with high livestock resource that was good input for the preparation of manures. Yazachew and Kasahun, (2011) reported that the study area is well known with the livestock resource. Livestock population size of the district was about 1095916 during year 2000.

All agricultural activities are under small-scale peasant holdings. There is no large scale private as well as state farm in the district. The use of modern agricultural inputs is very low, especially inorganic fertilizers for its high cost and poor accessibility. Highland parts of Gudji Zone have humid and sub humid moisture condition, which have longer growing season. Most cereal crops like maize take too long to mature. But vegetable crops like cabbage and Irish potato which are dominantly cultivated by the farmers mature in short growing season, less than four months. Therefore, optimum yields with high quality cabbages can be gained with integration of organic and inorganic fertilizers.

Basically there has been no research carried out on response of cabbage to chemical and organic fertilizer application and recommendations in the country. Cabbage is a heavy nitrogen and potassium feeder. When soils are infertile, higher amounts of nitrogen and potassium should be applied compared to phosphorus for head cabbage (Sorensen, 2003). Experiments done in India showed that treatment combinations with organic and inorganic fertilizers recorded significantly higher cabbage head yield $\left(42.42 \mathrm{t} \mathrm{ha}^{-1}\right)$ over the control with an addition of $150 \mathrm{~kg} \mathrm{~N} \mathrm{ha}^{-1}$ fertilizer in combination with $10 \mathrm{t} \mathrm{ha}^{-1}$ FYM over the control head yield $\left(38.10 \mathrm{tha}^{-1}\right)$. In another field experiments the application of $240 \mathrm{~kg} \mathrm{~N}, 45 \mathrm{~kg} \mathrm{P}, 180 \mathrm{~kg} \mathrm{~K}$ and $45 \mathrm{~kg} \mathrm{~S} \mathrm{ha}^{-1}$ performed best in recording plant height, root length, number of loose leaves and heading leaves, leaf length and breadth, thickness and diameter of head and yield. The maximum marketable yield $(87.09 \mathrm{t} / \mathrm{ha})$ was recorded in an application of $240 \mathrm{~kg} \mathrm{~N}, 45 \mathrm{~kg} \mathrm{P}^{-1}$ (Brady, 2003). Lesic et al. (2004) reported that cabbage has high requirements for all nutrients, especially nitrogen and for achieving high yields it ranged from 130 to $310 \mathrm{~kg} \mathrm{~N} \mathrm{ha}{ }^{-1}$

Due to the unavailability and high cost of chemical fertilizers, most smallholder farmers in tropical Africa, like Ethiopia, insufficiently use inorganic fertilizers on production of crops. Most smallholder farmers in Ethiopia practice application of inorganic fertilizers below the recommended rates for crop production (Bumb and Baanate, 1996). On the other hand, organic fertilizers are still a primary source of mineral elements, particularly among the resource-poor farmers of developing countries. But the use of organic fertilizers such as farm yard manure for crop production depends largely on the prevailing farming system. Organic manures also are an important source of plant nutrients but contain relatively in small amounts, which are not readily available. On the other hand, inorganic fertilizer contains specific, higher, and readily available plant nutrients. So the combination of organic manures and inorganic fertilizers is likely to be more productive.

In the study area where crop and livestock production are somewhat integrated, farmyard manure could become a major nutrient source for crops and reduce the need for the costly inorganic fertilizers. Moreover, nutrients contained in organic manures are released more slowly and are stored for a longer time in the soil, thereby ensuring a long residual effect thus supporting better root development, leading to higher crop yields (Bhuiyan, 2010). However, the use of organic fertilizers alone, to sustain cropping has been reported to be inadequate due to unavailability in the required quantities and their relatively low nutrient contents (Palm et al., 1997).

Thus, the combined use of organic and inorganic fertilizer sources can improve soil health and maximize production of cabbage, and as it involves utilization of local resources is assumed to be rational, realistic and economically viable way of supplying of nutrients to crop. MoARD (2011) on crop variety register bulletin indicated to use $235 \mathrm{~kg} \mathrm{ha}^{-1} \mathrm{~N}$ and $110 \mathrm{~kg} \mathrm{ha}^{-1} \mathrm{P}$ for production of head cabbage. However, access to new and improved agricultural technologies is highly limited in Gudji zone of Oromia Region most probably due to remoteness from the center and inaccessibility of the area. The potential of horticultural crops especially vegetables is not exploited in this part of the region due to lack of improved varieties, poor management practices, biotic and abiotic stresses high intensity and long duration of rainfall. So far the research institutions in 
the country have released many varieties of horticultural crops including cabbage. However, these technologies have not reached in full package to farmers in the study area. Thus, lack of improved management practices are the main production constraints of the area.

Therefore, this study was conducted to assess the effect of combined application of nitrogen and farmyard manure on growth, yield and yield components of head cabbage and to identify economically appropriate rates of nitrogen and farmyard manure that maximize yield of head cabbage.

\section{MATERIALS AND METHODS}

\subsection{Description of the Study Sites}

The experiment site is located in southern Ethiopia in one of the highland and high rainfall areas of the Oromia National Regional State. The site is found in Bore woreda about $8 \mathrm{~km}$ west of the town in Songo Bericha Kebele just on the side of the main Addis Ababa to Borena Negelle road via Awasa. It is about $385 \mathrm{~km}$ south from Addis Ababa. Geographically, the experimental site is situated at latitude of $6^{\circ} 26^{\prime} 52^{\prime \prime} \mathrm{N}$, longitude of $38^{\circ} 56^{\prime} 21^{\prime \prime} \mathrm{E}$ and at an altitude of 2736 masl. The climatic condition of the area is moist humid and sub humid moisture condition, with relatively longer growing season. The area is found at the annual rainfall ranges from 1400-1800 mm with a bimodal pattern that extended from April to November (Anonymous, 2013). The mean annual minimum and maximum temperature is $10.1{ }^{0} \mathrm{C}$ and $20{ }^{\circ} \mathrm{C}$, respectively. The type of the soil of the experimental site is red basaltic soil (Nitosols) and Orthic Aerosols. The soil is clay loam in texture and moderately acidic with $\mathrm{pH}$ around 6.5 (Yazachew and Kasahun, 2011).

\subsection{Description of the Experimental Materials}

Thomas F1 variety was used as experimental material. The seed of this variety were collected from the Seed Project Company Limited, Bejo Seed B.V. Crop Grow Crop Production PLC. The choice of this vegetable was due to its adaptability and short vegetative cycle. The seed of variety is found in the market at large, it is widely cultivated, and consumed in different highland parts of the zone. Urea $(46 \% \mathrm{~N})$, DAP $\left(46 \% \mathrm{P}_{2} \mathrm{O}_{5}+18 \% \mathrm{~N}\right)$ and TSP $\left(20 \% \mathrm{P}_{2} \mathrm{O}_{5}\right)$ for control treatments was used as sources of $\mathrm{N}$ and $\mathrm{P}$, respectively. Animal dung was collected and composted in a pit for five months to produce farmyard manure. The chemical nutrient content of the farmyard manure was analyzed and summarized as indicated in the appendix table 3.

Table 1. Description of the variety (Thomas F1) used for the experiment

\begin{tabular}{|c|c|}
\hline Description & Agronomic and morphological Characteristics \\
\hline Altitude (meters above sea level) & $1500-2200$ \\
\hline Rainfall amount (mm) & $800-1200$ \\
\hline Seeding rate $(\mathrm{kg} / \mathrm{ha})$ & 0.55 \\
\hline Planting season & Year round \\
\hline Spacing & $50 \mathrm{~cm}$ between rows and $40 \mathrm{~cm}$ between plants \\
\hline Days to maturity (days) & 80 days from transplanting \\
\hline Head color & Deep green \\
\hline Plant height $(\mathrm{cm})$ & $40-50$ \\
\hline Head shape & Round compact \\
\hline Growth Habit & Erect with blue wrapper leaves \\
\hline Average head weight (g) & 2000 \\
\hline Yield (kg/ha) & 700 \\
\hline Year of Release & 2011 \\
\hline
\end{tabular}

Source: MoA (2011) Crop Variety Register Bulletin

\subsection{Treatments and Experimental Design}

The experiment was arranged in factorial combination of four level of farmyard manure $\left(0,3,6\right.$ and 10 tons ha $\left.^{-1}\right)$ and five levels of Nitrogen $\left(0,59,119,235\right.$ and $\left.294 \mathrm{~kg} \mathrm{ha}^{-1}\right)$ while DAP for nitrogen containing and TSP for control treatments will be applied for all plots The experiment was laid out in randomized complete block design (RCBD) in factorial combination with three replications. The spacing of the plants was $50 \mathrm{~cm}$ between rows and $40 \mathrm{~cm}$ between plants. The distance between plot and block was $0.8 \mathrm{~m}$ and $1.2 \mathrm{~m}$, respectively. Six rows per plot and nine plants per row, totally 54 plants per plot were established in gross plot size of $3 \mathrm{~m}$ by $3.6 \mathrm{~m}$. Therefore the net experimental or harvestable plot size of $2 \mathrm{~m}$ by $3.6 \mathrm{~m}$ was used

\subsection{Soil and Farmyard Manure Sampling and Analysis}

Soil samples to a depth of $30 \mathrm{~cm}$ were collected in a zigzag way from different spots of the experimental field before land preparation and after harvest were taken and composited. After harvest soil sampling was taken in the same manner as taken for the pre planting in a zizag way from 15 different plots. Then the composite samples were analyzed for physico-chemical properties of the soil mainly for organic carbon, total $\mathrm{N}$, soil $\mathrm{pH}$, 
available phosphorus, cation exchangeable capacity (CEC), and texture at Melkasa and Holeta Agricultural Research Center soil laboratories for soil and manure, respectively. The soil $\mathrm{pH}$ was measured potentiometrically in the supernatant suspension of 1:2.5 soil-water suspensions with standard glass electrode $\mathrm{pH}$ meter (Van Reeuwijk, 1992). The Walkley and Black (1934) method was used to determine the organic matter content and the result was obtained by multiplying percent organic carbon by a conversion factor of 1.724 . The total nitrogen content of the sampled soil was determined following Kjeldahl digestion, distillation and titration procedure as described by Cottenie (1980). Besides, available phosphorus was determined by Olsen et al. (1954) method. The cation exchange capacity (CEC) was measured using 1M-neutral ammonium acetate (Jackson, 1967). The soil particle size distribution was determined using the hydrometer technique (Ryan et al., 1965). The manure sample was taken from the well decomposed collected material. The manure was collected from known farmer near to the experimental site and composted the research station site, and air dried, and analyzed at laboratory for $\mathrm{pH}$, total $\mathrm{N}$, available $\mathrm{P}$, available $\mathrm{K}, \mathrm{CEC}$ and organic carbon content.

The analytical results indicated that the textural class of the soil was sandy clay loam soil profile (Appendix Table 1). Accumulation of different organic materials during previous growing seasons might have resulted in very high pre-plant organic carbon content $(3.32 \%)$, which might have contributed to the medium level of total $\mathrm{N}$ $(0.21 \%)$, medium level of available phosphorus $(5.3 \%)$, high level of available potassium $\left(7.41 \mathrm{cmol}^{(+)} \mathrm{kg}^{-1}\right)$, high organic matter $(5.73 \%)$ and medium level of CEC $\left(13.26 \mathrm{cmol}(+) \mathrm{kg}^{-1}\right)$ in the soil. Berhanu (1980) and Tekalign et al.(1991) rated $0.12-0.25 \%$ total $\mathrm{N}$ as medium, $>5.17 \% \mathrm{OM}$ as high and available phosphorus range $5-10 \mathrm{mg} \mathrm{kg}^{-1}$ as medium while available $\mathrm{K}$ range $0.6-1.2 \mathrm{cmol}(+) \mathrm{kg}^{-1}$ as high.

The soil $\mathrm{pH}$ was also slightly acidic with a value of $6.2\left(\mathrm{pH}-\mathrm{H}_{2} \mathrm{O}\right)$. Cation exchange capacity (CEC) is an important parameter of soil, because it gives an indication of the type of clay mineral present in the soil and its capacity to retain nutrients against leaching. Accordingly, CEC of the experimental soil $\left(13.26 \mathrm{cmol} \mathrm{kg}^{-1}\right) \mathrm{could}$ be considered as optimum for production of the crop.

Generally, the soil physical and chemical analysis results indicated that the soils of the experimental fields are potentially productive from the perspectives of chemical properties of soils for cabbage growth and had a potential to respond to fertilizer application.

\subsection{Management of the Experiment}

The seedlings were grown on the well prepared nursery seedbed and transplanted at 45 days after sowing. Before conducting the research, nursery bed preparation and sowing was done. The nursery was prepared at by removing plant residues and breaking bigger soil particles. At the same seeds of cabbage bought from Bejo Seed B.V. crop production PLC and were raised in the nursery 45 days before transplanting and watered once a day until the seedlings were ready to be transplanted. Only short sturdy, slightly hardened seedlings of about 10-15 $\mathrm{cm}$ tall and with 4-5 true leaves was transplanted. Replanting or refilling was done after ten days for the missed plot. The land was loosened three times with tractor and oxen power. Six to nine months old animal dung was collected and composted in a pit for five months to produce farmyard manure. The composted farmyard manure was applied to the soil one month before planting and incorporated into the soil in order to combine well with soil. Before spreading farmyard manure, the soil was loosened to a depth of $30 \mathrm{~cm}$; thereafter the soil was moistened to prevent the farmyard manure from drying. All doses of nitrogen and $\mathrm{P}$ were applied once at time of transplanting. Other agronomic practices including weeding, gap filling and cultivation were done uniformly as per required in all plots.

\subsection{Crop Data Collection}

3.6.1. Phenological Data

Days to head initiation: Days to $50 \%$ head initiation was recorded when half of the plants in a net plot formed heads.

Days to head maturity: It was recorded from the date of transplanting to when $90 \%$ of the heads from the net plot reached maturity. This was determined by the compactness or firmness of the head.

3.6.2. Growth Parameters

Plant height: The height of the plant was measured by placing a meter scale from ground level to the tip of the outer longest leaf of an individual plant at the time of $90 \%$ days to head maturity. Thus, mean of five selected plants of a single plot was recorded and expressed in centimeter $(\mathrm{cm})$.

Number of expanded leaves per plant: The number of leaves per plant was counted and mean of five plants was recorded before the start of head initiation excluding unfolded and dead leaves.

3.6.3. Yield and Yield Components

Field Stand Count: Field stand count was recorded at harvesting from net plot areas.

Shoot mass: Shoot fresh mass was obtained by taking the weight of shoots separately from five representative plants per plot by uprooting and cutting at harvest and finally converted to g per plot.

Height of head: Head height $(\mathrm{cm})$ was obtained from five representative plants per plot and measured by cutting 
vertically using a ruler at the time of harvesting.

Diameter of head: Five heads were taken randomly. Then sectioning of head was done horizontally with a sharp knife at the middle portion. The diameter of head was measured as the horizontal distance from one side to another side of the selected head and was expressed in centimeter $(\mathrm{cm})$.

Fresh weight of untrimmed head per plant: The fresh weight of heads with unfolded leaves per plant was found from the average weight of selected five plants and expressed in gram (g) when yield data was taken.

Fresh weight of trimmed head per plant: The fresh weight of marketable head per plant was found from the average weight of five plants and was expressed in gram $(\mathrm{g})$ when yield data was taken.

Gross head yield with wrapper: Heads with unfolded leaves of all the plants within a net plot (harvested area 2 $\mathrm{m} \times 3.6 \mathrm{~m}$ ) was recorded and converted to tons per hectare.

Marketable yield per plot: Heads without unfolded leaves of all the plants head within a net plot (harvested area $2 \mathrm{~m} \times 3.6 \mathrm{~m}$ ) was recorded and converted to tons per hectare.

Fresh Biomass Yield: It was obtained by recording all the above ground plant parts of five sampled plants and expressed in kg per plot and later converted to tons per hectare.

\subsection{Partial Budget Analysis}

Cost benefit analysis was done to determine the relative economic returns on the applied treatments using the prevailing market prices. The yields were adjusted by $10 \%$ downwards due to management level variability between a researcher and a farmer (CIMMYT, 1988). Costs of farm services were taken at Bore market in the southern part of Ethiopia. The economic indicators used were:

Gross Benefit: This is the product of the adjusted yield $\left(\mathrm{t} \mathrm{ha}^{-1}\right)$ and the sale prices. It was calculated by multiplying the yield in $\mathrm{tha}^{-1}$ by the market price.

Net Benefit: It was calculated by subtracting the total cost of production from the gross benefit.

Marginal Analysis: This compares the net benefits with the total variable cost. The total variable cost was determined for each treatment and was compared with the net benefit.

Dominance Analysis: Treatments were arranged in terms of increasing variable costs. The corresponding net benefits were also indicated. A treatment is dominant when it has a higher cost but a lower net benefit than any preceding treatment.

Marginal Rate of Returns (MRR): It is the percentage change in benefit over change in total variable cost in moving from a lower cost treatment to a higher one. All the treatments were arranged from the highest to the lowest in terms of profitability. This was achieved by dividing the total variable cost by the net benefit multiplied by 100 .

$$
\operatorname{MRR}(\%)=\frac{\text { Marginal benefit } \times 100}{\text { Marginal Cost }}
$$

\subsection{Statistical Data analysis}

The collected data on various parameters of the crop under study were statistically analyzed using SAS statistical package (Gomez and Gomez, 1984). The Least Significant Difference (LSD) test at 5\% level of significance was used to separate the means when the ANOVA showed the presence of significant difference.

\section{RESULTS AND DISCUSSION}

The present experiment was conducted to find out the combination effects of nitrogen and farmyard manure on growth and yield of cabbage. Therefore, the effects of nitrogen and farmyard manure and their interaction effects on growth and yield of cabbage have been presented and discussed in different tables and figures in this chapter. The analysis of variance of the data of different yield contributing characters and yield has been presented in Appendices. The results of the experiment and possible interpretations have been made under the following headings. With this the Soil and Farmyard Manure laboratory analysis was presented in table below. 
Table 2. Background of chemical and physical properties of experimental site soil before planting.

\begin{tabular}{ll}
\hline Soil characters & Values \\
\hline $\mathrm{pH}$ & 6.2 \\
Total nitrogen $(\%)$ & 0.21 \\
Organic carbon $(\%)$ & 3.32 \\
Available $\mathrm{P}\left(\mathrm{mg} \mathrm{kg}^{-1}\right)$ & 5.3 \\
$\mathrm{CEC}\left(\mathrm{cmol}(+) \mathrm{kg}^{-1}\right)$ & 13.26 \\
Available K $\left(\mathrm{me}^{-100 \mathrm{~g}}\right.$ soil) & 7.41 \\
Organic matter $(\%)$ & 5.73 \\
$\mathrm{Mg}\left(\mathrm{cmol}(+) \mathrm{kg}^{-1}\right)$ & 6.12 \\
Soil texture: & \\
Sand & 52 \\
Silt & 20 \\
Clay & 28 \\
Class & Sand clay loam \\
\hline
\end{tabular}

Table 3. Soil physical properties at experimental site after FYM and N decomposition and harvest

\begin{tabular}{ll}
\hline Soil characters & Values \\
\hline $\mathrm{pH}$ & 6.31 \\
Total nitrogen $(\%)$ & 0.36 \\
Organic carbon $(\%)$ & 3.55 \\
Available P $(\mathrm{ppm})$ & 5.42 \\
$\mathrm{CEC}(\mathrm{cmol}(+) / \mathrm{kg})$ & 12.23 \\
Available K $(\mathrm{cmol}(+) / \mathrm{kg})$ & 7.53 \\
Organic matter $(\%)$ & 6.12 \\
Soil texture: & \\
Sand $(\%)$ & 49 \\
Silt $(\%)$ & 23 \\
Clay $(\%)$ & 28 \\
Class & Sandy clay loam \\
\hline
\end{tabular}

Table 4. Chemical properties of farmyard manure used in the experiment

\begin{tabular}{ll}
\hline FYM characters & Values \\
\hline $\mathrm{pH}$ & 6.5 \\
Total nitrogen $(\%)$ & 0.356 \\
Organic carbon $(\%)$ & $31.13 \mathrm{~g}$ \\
Available $\mathrm{P}(\mathrm{ppm})$ & 38.85 \\
$\mathrm{CEC}\left(\mathrm{cmol}(+) \mathrm{kg}^{-1}\right)$ & 26.11 \\
Available K $\left(\mathrm{cmol}^{(+)} \mathrm{kg}^{-1}\right)$ & 2.53 \\
\hline
\end{tabular}

\subsection{Plant Height and Number of Expanded Leaves}

\subsubsection{Plant Height}

Nitrogen and Farm yard manure fertilization has a very highly significantly $(\mathrm{P}<0.001)$ increased most of the growth parameters considered in this study. So plant height was increased highly significantly $(\mathrm{P}<0.001)$ with main effect of nitrogen supply and also for the manure application (Appendix Table 6). All the treatment combinations with $\mathrm{N}$ and FYM were recorded significantly different cabbage plant height. There was also a highly significant $(\mathrm{P}<0.001)$ interaction effect of the nutrients on the plant height of the crop (Table 2). Thus there were significance differences between the mean plant heights $(43.2 \mathrm{~cm})$ versus FYM of $\left(10 \mathrm{t} \mathrm{ha}^{-1}\right)$ with each level of N $\left(235 \mathrm{~kg} \mathrm{ha}^{-1}\right)$ for plant height. Similarly the treatments received FYM of $\left(10 \mathrm{t} \mathrm{ha}^{-1}\right)$ with each level of $\mathrm{N}\left(294 \mathrm{~kg} \mathrm{ha}^{-1}\right)$ also shows highest mean plant height $(41.61 \mathrm{~cm})$. This means treatments receiving highest nutrient of $10 \mathrm{tha}^{-1}$ versus $235 \mathrm{~kg} \mathrm{~N}$ and $294 \mathrm{Kg} \mathrm{N} \mathrm{ha}^{-1}$ responds the same. As it was observed from the data the plant height has an increasing trend in plant height growth considered with in increasing combined rate of applied N and FYM. Similar results were noted by Sarker et al., 1996 that significance in plant height of cabbage was observed as the rate of N and FYM increased. Sanderson and Ivany (1999) have also reported that increase in Nitrogen levels up to $150 \mathrm{~kg} \mathrm{ha}^{-1}$ and phosphorus levels up to $120 \mathrm{~kg} \mathrm{ha}^{-1}$ increased plant height of head cabbage over its lower levels. Baloch et al. (2001) experiment on head cabbage result signifies that increased use of Nitrogen and FYM leads to increased plant height. This result is in agreement with that of Sarker et al. (2003) who observed that good plant height obtained in response to increased $\mathrm{N}$ supply improved significantly due to 
the presence of FYM.

The increment in plant height due to FYM application may be due to the fact that organic fertilizer improves the soil structure and aggregation; this change can improve availability of nutrients as well as encourage the plant to have good root development by improving the aeration in the soil, which leads to a higher plant growth. In our study there was an increasing trend in the plant height parameter with the increasing in the rate of applied both $\mathrm{N}$ and FYM.

Table 5. Interaction Effect of $\mathrm{N}$ and $\mathrm{M}$ on Plant Height of Head Cabbage $\left(\mathrm{Cm} \mathrm{Plant}^{-1}\right)$

\begin{tabular}{lccccc} 
Manure $\left(\right.$ ton $\left.\mathrm{ha}^{-1}\right)$ & \multicolumn{5}{c}{ Nitrogen $\left(\mathrm{kg} \mathrm{ha}^{-1}\right)$} \\
\cline { 2 - 6 } 0 & 0 & 59 & 119 & 235 & 294 \\
\cline { 2 - 6 } 3 & $26.64^{\mathrm{f}}$ & $27.38^{\mathrm{f}}$ & $31.93^{\mathrm{e}}$ & $32.47^{\mathrm{e}}$ & $34.12^{\text {cde }}$ \\
6 & $26.83^{\mathrm{f}}$ & $33.13^{\mathrm{de}}$ & $31.83^{\mathrm{e}}$ & $33.81^{\text {cde }}$ & $34.93^{\text {cd }}$ \\
10 & $27.64^{\mathrm{f}}$ & $33.22^{\text {de }}$ & $34.01^{\text {cde }}$ & $37.73^{\mathrm{b}}$ & $37.98^{\mathrm{b}}$ \\
& $27.7^{\mathrm{f}}$ & $32.44^{\mathrm{e}}$ & $35.72^{\mathrm{bc}}$ & $43.20^{\mathrm{a}}$ & $41.61^{\mathrm{a}}$
\end{tabular}

$\operatorname{LSD}(0.05) \mathrm{N} * \mathrm{M}=2.36 ; \mathrm{CV}(\%)=4.32$

\subsubsection{Number of Expanded Leaves}

Different level of Nitrogen and Farmyard manure fertilization alone has highly significantly differently $(\mathrm{P}<0.001)$ increased number expanded leaves in the study. So plant leaves was increased highly significantly $(\mathrm{P}<0.001)$ with main effect of nitrogen and farmyard manure supply also for the interaction effect of both $\mathrm{N}$ and FYM application.

In this parameter all the treatment combinations with $\mathrm{N}$ and FYM were recorded significantly different cabbage number of expanded leaves (Table 3). The highest Number expanded leaves (16.66) of cabbage plants tended to increase by increasing combined dose of organic manure and inorganic $\mathrm{N}$ fertilizers. Also, number of leaves per plant showed a little increase with increased organic manure dose $\left(10 \mathrm{t} \mathrm{ha}^{-1}\right)$ and Nitrogen fertilizer $\left(294 \mathrm{~kg} \mathrm{ha}^{-1}\right)$. Each increase in Nitrogen and FYM fertilizer dose tended to increase number of leaves per plant compared with control. Generally, plots receiving a combined nutrient of N and FYM fertilizers produced higher $(\mathrm{P}<0.001)$ number of leaves. Thus, through the increase in photosynthetic activity of leaves, it further encourages vegetative growth of plants as reported by (Archer. 1988; Marschner.1995). These results are in accordance with Magnusson (2002) on chinensis cabbage (Brassica chinesis) that he observed highest numbers of leaves of Chinese cabbage were obtained by application of 10 ton ha ${ }^{-1}$ organic manure with combination of $200 \mathrm{~kg} \mathrm{ha}^{-1}$ nitrogen fertilizer.

Our ANOVA result revealed that the number of cabbage leaves increased as organic fertilizer rates increased (Table 3). Khadir et al. (2002) also observed suggested that combined application of different inorganic and organic fertilizers increased both vegetative and leaf number in cabbage growth. They noticed that application of $20 \mathrm{t} \mathrm{ha}^{-1} \mathrm{FYM}$ with combined rate of $250 \mathrm{~kg} \mathrm{~N} \mathrm{ha}^{-1}$ produces more expanded leaves instead of compact head. In cabbage, leaves play an important role for photosynthesis. For this reason, the number of leaves per plant was an important yield-contributing factor. In this experiment, generally it was found that different level of nitrogen and FYM practices had showed significant $(\mathrm{P}<0.001)$ effect on plant height and number of leaves per plant. The highest rate of nutrients application resulted in plants with more vegetative and leaf growth as compared to the lower rates which could be attributed to the low initial content of N and FYM. The number of leaves had a trend of increased gradually from control and reached its peak at $294 \mathrm{~kg} \mathrm{~N}^{-1}$ with $10 \mathrm{tha}^{-1}$ manure. Gulser (2005) Also showed that there was a significant difference in the number of leaves among different level of combined application of $200 \mathrm{~kg} \mathrm{~N} \mathrm{ha}^{-1}$ and $15 \mathrm{tha}^{-1}$ organic manure that the highest leaf number was obtained with. Vimala et al. (2006) also reported that increments in the $\mathrm{N}$ rate of the fertilizers with FYM increased the number of leaves in spinach. Therefore combined application of organic and inorganic fertilizer stimulated vegetative growth by increasing the number of leaves.

Table 6.Interaction effect of $\mathrm{N}$ and $\mathrm{M}$ on number of expanded leaves of head cabbage (leaves/plant)

\begin{tabular}{|c|c|c|c|c|c|}
\hline \multirow[t]{2}{*}{ Manure $\left(\right.$ ton $\left.\mathrm{ha}^{-1}\right)$} & \multicolumn{5}{|c|}{ Nitrogen $\left(\mathrm{kg} \mathrm{ha}^{-1}\right)$} \\
\hline & 0 & 59 & 119 & 235 & 294 \\
\hline 0 & $10.33^{\mathrm{h}}$ & $10.66^{\mathrm{gh}}$ & $13.33^{\text {cde }}$ & $12.33^{\mathrm{def}}$ & $12.00^{\text {efg }}$ \\
\hline 3 & $10.66^{\mathrm{gh}}$ & $12.66^{\mathrm{def}}$ & $13.66^{\mathrm{cd}}$ & $13.66^{\mathrm{cd}}$ & $12.66^{\mathrm{def}}$ \\
\hline 6 & $11.33^{\text {fgh }}$ & $13.66^{\mathrm{cd}}$ & $13.66^{\mathrm{cd}}$ & $14.66^{\mathrm{bc}}$ & $14.66^{\mathrm{bc}}$ \\
\hline 10 & $12.66^{\mathrm{def}}$ & $13.33^{\text {cde }}$ & $14.66^{\mathrm{cb}}$ & $15.66^{\mathrm{ab}}$ & $16.66^{\mathrm{a}}$ \\
\hline
\end{tabular}

\subsection{Days to $50 \%$ Head Initiation and $90 \%$ Maturity of Cabbage}

4.2.1. Days to $50 \%$ Head Initiation

The main effect of $\mathrm{N}$ was highly significant $(\mathrm{P}<0.001)$ on this parameter to reach head initiation. FYM had also highly significantly $(\mathrm{P}<0.001)$ different main effect on head initiation, and also the interaction effect of both $\mathrm{N}$ 
and FYM show highly significant different $(\mathrm{P}<0.001)$ on this parameter (Appendix Table 6). Days to start of head formation from transplanting of Chinese cabbage showed significant differences $(\mathrm{P}<0.001)$ with different levels of nitrogen with combined FYM application in the present trial. All the combined level of nitrogen fertilizer with FYM showed a gradual retarding tendency of days to starting head formation of Chinese cabbage as the dose decreased (Table 4). The shortest head initiation duration (63.33) was recorded in $294 \mathrm{~kg} \mathrm{~N} \mathrm{ha}^{-1}$ and 10 ton manure $\mathrm{ha}^{-1}$, where the longest (81.66) was recorded in control. The results indicated that the treatments received high doses of nutrients resulted in delayed of different reproductive growth phases whereas the onset of different reproductive phases were drastically hastening in case of plants received low rate of nutrients or no nutrients. This result agreed with Chaubey et al. (2006) who found significantly shorter time (57.45) of cabbage for head initiation under the treatment receiving nitrogen and farmyard manure fertilizer ahead of control treatment.

The ANOVA result revealed that days to head initiation inversely correlated with the nutrient rates. That means as the combined rate increased the days 50\% head formation negatively decreased. In another interpretation the more we use the nutrients the early the crop head to form. Haque et al. (2006) also observed that higher fertility level favored the head initiation and maturity of head cabbage.

Table 7. Interaction effect of $\mathrm{N}$ and $\mathrm{M}$ on days of $50 \%$ head initiation of head cabbage (days)

\begin{tabular}{lrrrrr}
\hline Manure $($ ton ha & -1 $)$ & \multicolumn{5}{c}{ Nitrogen $\left(\mathrm{kg} \mathrm{ha}^{-1}\right)$} \\
\cline { 2 - 5 } 0 & 0 & 59 & 119 & 235 & 294 \\
\cline { 2 - 6 } 3 & $81.66^{\mathrm{a}}$ & $77.66^{\mathrm{b}}$ & $72.66^{\mathrm{c}}$ & $68.66^{\mathrm{d}}$ & $64.33^{\mathrm{e}}$ \\
6 & $78.33^{\mathrm{b}}$ & $78.00^{\mathrm{b}}$ & $72.00^{\mathrm{c}}$ & $67.66^{\mathrm{d}}$ & $64.00^{\mathrm{e}}$ \\
10 & $77.33^{\mathrm{b}}$ & $73.00^{\mathrm{c}}$ & $63.66^{\mathrm{e}}$ & $63.33^{\mathrm{e}}$ & $63.33^{\mathrm{e}}$ \\
LSD $(0.05)=1.43 ; \mathrm{CV}(\%)=1.22$ & $73.33^{\mathrm{c}}$ & $72.00^{\mathrm{c}}$ & $73.33^{\mathrm{c}}$ & $67.66^{\mathrm{d}}$ & $63.33^{\mathrm{e}}$
\end{tabular}

4.2.2. Days to $90 \%$ Maturity of Cabbage

The main effect of $\mathrm{N}$ was highly significant $(\mathrm{P}<0.001)$ on days to maturity. FYM had also highly significantly $(\mathrm{P}<0.001)$ different main effect on days to maturity, and also the interaction effect of both $\mathrm{N}$ and FYM show highly significant different $(\mathrm{P}<0.001)$ on this parameter (Appendix Table 6).

The interaction effect of Nitrogen and FYM rate showed significant difference $(\mathrm{P}<0.001)$ in days to maturity (Table 5). Head cabbage planted in combination of Nitrogen $\left(294 \mathrm{~kg} \mathrm{ha}^{-1}\right)$ and Farmyard manure $(10$ ton $\mathrm{ha}^{-1}$ ) matured earlier (112) compared to other treatments. Treatments treated with highest combination rates took shorter period to mature as compared to control treatment. This is because of the effect of both high rate of $\mathrm{N}$ and FYM in delaying the vegetative phase and hastening head formation and maturity of different reproductive growth phases. Generally cabbage that received the highest N and FYM rates reached maturity earlier than those received no or low $\mathrm{N}$ rates. This result is in agreement with that Wilcox and Hoff (1970), who reported that combined use of inorganic and organic nutrients was associated with delays in plant maturity. This is because of the essential nutrients accelerated the plant growth. In contrast to $\mathrm{N}$, however it hastened maturity of the plants. Thus, the cabbage plant treated with highest nutrients supply had their time to physiologically mature earlier by 27 days compared to the untreated treatments. Rosen and Eliason (2005) demonstrated the importance of $\mathrm{N}$ for early crop growth and crop to mature. Sisay et al. (2008) reported that the shortest duration of carrot plants to reach maturity was recorded for the highest level of $\mathrm{N}\left(309 \mathrm{~kg} \mathrm{ha}^{-1}\right)$ and P $\left(68 \mathrm{~kg} \mathrm{ha}^{-1}\right)$ who reported that excessive $\mathrm{N}$ fertilizer hastened maturity of crop plants while low levels of $\mathrm{N}$ delayed the maturity. Table 8. Interaction effect of $\mathrm{N}$ and $\mathrm{M}$ on days of $50 \%$ maturity of head cabbage (Days)

\begin{tabular}{|c|c|c|c|c|c|}
\hline \multirow[t]{2}{*}{ Manure (ton $\mathrm{ha}^{-1}$ ) } & \multicolumn{5}{|c|}{ Nitrogen $\left(\mathrm{kg} \mathrm{ha}^{-1}\right)$} \\
\hline & 0 & 59 & 119 & 235 & 294 \\
\hline 0 & $140.66^{\mathrm{a}}$ & $135^{b}$ & $127.66^{\text {cde }}$ & $122.00^{\text {fgh }}$ & $113.66^{1}$ \\
\hline 3 & $133.33^{\mathrm{b}}$ & $128.00^{\mathrm{cd}}$ & $127.66^{\mathrm{cde}}$ & $118.66^{\mathrm{h}}$ & $113^{\mathrm{i}}$ \\
\hline 6 & $129^{\mathrm{c}}$ & $127.66^{\text {cde }}$ & $119.66^{\mathrm{h}}$ & $119.33^{\mathrm{h}}$ & $112.00^{\mathrm{i}}$ \\
\hline 10 & $123.66^{\mathrm{efg}}$ & $124^{\mathrm{def}}$ & $118.66^{\mathrm{h}}$ & $112.66^{\mathrm{i}}$ & $113.00^{\mathrm{i}}$ \\
\hline $\operatorname{LSD}(0.05)=4.09$ & & & & & \\
\hline
\end{tabular}

\subsection{Field stand count}

Analysis of data for both nitrogen and farmyard manure revealed non-significant $(\mathrm{P}>0.05)$ main effect on field stand count. Also the interaction effect of both $\mathrm{N}$ and FYM had non-significant $(\mathrm{P}>0.05)$ on this parameter.

\subsection{Head Height and Head Diameter}

4.4.1. Head Height

Analysis of data for both nitrogen and farmyard manure revealed highly significant $(\mathrm{P}<0.001)$ main effect on head height (Appendix Table 6). Also the interaction effect of both $\mathrm{N}$ and FYM had also significant different effect $(\mathrm{P}<0.001)$ on this parameter (Table 6). Nitrogen and FYM fertilization had significant $(\mathrm{P}<0.001)$ 
interaction effect on head height of the crop. The combined effect of nitrogen and FYM was important for most of the characters of head cabbage (Table 6). Combined application of $235 \mathrm{~kg}$ nitrogen and $6 \mathrm{t} \mathrm{FYM} \mathrm{ha}{ }^{-1}$ recorded highest head height $(18.14 \mathrm{~cm})$. The least head height $(13.86 \mathrm{~cm})$ was recorded for the treatment received highest $\left(294 \mathrm{~kg} \mathrm{ha}^{-1}+10 \mathrm{tha}^{-1}\right)$ amount of applied nutrients. The head height obtained by fertilizing $235 \mathrm{~kg} \mathrm{~N}+6 \mathrm{t} \mathrm{FYM}$ $\mathrm{ha}^{-1}$ was $76.4 \%$ higher than those of the over fertilized treatment and also $78.9 \%$ higher than the control treatment. The height trend is increasing with an increase in the combined rate of $\mathrm{N}$ and FYM to the certain level but, decreases after $235 \mathrm{~kg} \mathrm{~N}+6 \mathrm{t} \mathrm{FYM} \mathrm{ha-1}$ rate. This result is in conformity with the observation of Ciszinszky and Schester (2001) that combined application of $200 \mathrm{~kg} \mathrm{~N} \mathrm{ha}^{-1}$ with $20 \mathrm{t} \mathrm{ha}^{-1} \mathrm{FYM}$ resulted in the highest head height of cabbage $(17.67 \mathrm{~cm})$.

Thus, the results of the experiment indicated a significant response of $\mathrm{N}$ and FYM with respect to head height. Krezel and Koota (2004) also conducted a research in Florida, to investigate the effect of nitrogen on yield of cabbage and found that nitrogen rate of $227 \mathrm{~kg} \mathrm{ha}^{-1}$ with $30 \mathrm{t} \mathrm{ha}^{-1}$ FYM increased head height $(19.23 \mathrm{~cm})$ of cabbage. Nutrient levels noticeably influenced the diameter and height of head cabbage. Balanced use of nitrogen and farmyard manure significantly increased the head height and reduced the percentage of deformed head as compared to lower and extremely high dose of nitrogen and farmyard manure. The results are also similar with the Journal of Crop and Weed, 5(2): 75-77 (2009) findings of Felozynski et al. (2004).

Table 9. Interaction effect of $\mathrm{N}$ and $\mathrm{M}$ on Head Height of head cabbage $(\mathrm{cm} / \mathrm{head})$

\begin{tabular}{lccccc} 
Manure (ton ha & -1) & \multicolumn{4}{c}{ Nitrogen $\left(\mathrm{kg} \mathrm{ha}^{-1}\right)$} \\
\cline { 2 - 6 } 0 & 0 & 59 & 119 & 235 & 294 \\
\cline { 2 - 6 } 3 & $14.32^{\text {ghij }}$ & $14.10^{\text {ij }}$ & $14.24^{\text {hij }}$ & $14.53^{\text {efghi }}$ & $14.64^{\text {defghi }}$ \\
6 & $14.41^{\text {fghij }}$ & $14.68^{\text {defghij }}$ & $15.23^{\text {cd }}$ & $16.36 \mathrm{~b}$ & $15.53^{\mathrm{c}}$ \\
10 & $14.99^{\text {cdef }}$ & $14.92^{\text {defg }}$ & $16.26^{\mathrm{b}}$ & $18.14^{\mathrm{a}}$ & $14.23^{\text {hij }}$ \\
& $14.82^{\text {defgh }}$ & $15.06^{\text {cde }}$ & $16.14^{\mathrm{b}}$ & $16.66^{\mathrm{b}}$ & $13.86^{\mathrm{j}}$
\end{tabular}

$\operatorname{LSD}(0.05)=0.59 ; \mathrm{CV}(\%)=2.4$

4.4.2. Diameter of Cabbage

Application of FYM also showed significantly different $(\mathrm{P}<0.001)$ main effect on Head diameter of head cabbage plant as like the height of the head (Appendix Table 6). Normally the increasing head height parallels with the head diameter expressed by positive and highly significant correlation value. Also the interaction effect of both $\mathrm{N}$ and FYM had also significant different effect $(\mathrm{P}<0.001)$ on this parameter (Table 7).

The interaction effect between Nitrogen and FYM combination was also highly significant $(\mathrm{P}<0.001)$ for head diameter under our study (Table 7). It was observed that $\mathrm{N}$ and FYM application at different levels recorded a remarkable change in diameter of head cabbage. Head diameter was increased with the increase nutrient doses up to $235 \mathrm{~kg} \mathrm{~N}$ and 6 ton $\mathrm{ha}^{-1}$ FYM. Similarly head diameter was increased with increase doses of nutrients till $235 \mathrm{~kg} \mathrm{~N}$ and $6 \mathrm{t} \mathrm{ha}^{-1}$ FYM in combination. Combined application of $235 \mathrm{~kg}$ nitrogen and 6 ton ha ${ }^{-1}$ recorded maximum number of head diameter $(17.03 \mathrm{~cm})$. The lowest head diameter $(12.49 \mathrm{~cm}$ and $12.52 \mathrm{~cm})$ was recorded for the treatment received no nutrients and highest $\left(294 \mathrm{~kg} \mathrm{ha}^{-1}+10 \mathrm{t} \mathrm{ha}^{-1}\right)$ amount of applied nutrients respectively. In this result our ANOVA summary revealed that both the control and $294 \mathrm{~kg}+10 \mathrm{t} \mathrm{FYM} \mathrm{ha}^{-1}$ treatment did not show significant differences. The interaction effect between nitrogen and farmyard manure combination was significant for most of the characters under our study. This result was corroborated with the findings of Peck (1998) in cabbage that the diameter of the head increased as the rate of application increased than the least applied treatments. Arisha et al. (2003) also reported that significantly higher diameter of head in cabbage by the application of 120-90-80 $\mathrm{kg} \mathrm{NPK} \mathrm{ha}^{-1}$ respectively, with a combination of $20 \mathrm{t} \mathrm{FYM} \mathrm{ha}^{-1}$. There was a strong positive correlation between diameter of head and marketable head per plant. Table 10. Interaction effect of $\mathrm{N}$ and $\mathrm{M}$ on Head Diameter of head cabbage (cm/head)

\begin{tabular}{lccccc}
\hline Manure (ton ha $\left.{ }^{-1}\right)$ & \multicolumn{4}{c}{ Nitrogen $\left(\mathrm{kg} \mathrm{ha}^{-1}\right)$} \\
\cline { 2 - 6 } 0 & 0 & 59 & 119 & 235 & 294 \\
3 & $12.49^{\mathrm{k}}$ & $13.80^{\mathrm{jjk}}$ & $13.12^{\text {ghijk }}$ & $13.52^{\text {ghij }}$ & $14.40^{\text {def }}$ \\
6 & $12.64^{\mathrm{jk}}$ & $13.45^{\text {ghij }}$ & $13.84^{\text {efg }}$ & $13.55^{\text {fghi }}$ & $15.41^{\text {bc }}$ \\
10 & $13.46^{\text {ghij }}$ & $13.49^{\text {ghij }}$ & $14.70^{\text {cde }}$ & $17.03^{\mathrm{a}}$ & $12.90^{\text {hijk }}$ \\
\cline { 2 - 6 } & $13.72^{\text {ggh }}$ & $13.82^{\text {fg }}$ & $14.98^{\text {cbd }}$ & $15.66^{\text {bd }}$ & $12.52^{\mathrm{k}}$
\end{tabular}

$\operatorname{LSD}(0.05)=0.88 \mathrm{CV}(\%)=3.83$

Regardless of organic manure dosages, each increase in inorganic fertilizers dose caused a gradually increased in diameter of heads at 0 and $119 \mathrm{~kg} \mathrm{~N} \mathrm{ha}^{-1}$. Application of $235 \mathrm{~kg} \mathrm{ha}^{-1}$ Nitrogen fertilizer with different organic manure doses produced significantly larger heads diameter compared with control and $294 \mathrm{~kg}$ $\mathrm{ha}^{-1}$ Nitrogen fertilizer. Positive effects of Nitrogen fertilizers and organic nutrients on head diameter of cabbage may be due to the better availability of soil nutrients that produced healthy plants with large vegetative growth, which reflected in the height and head diameter and improvement of soil chemical and physical properties by using Farmyard manure Wong et al. (1999).

All data indicated that, it is worthy to notice the positive effect of combined application of organic and 
inorganic fertilizer. It is obvious that farmyard manure had a promising effect on all growth parameters including height and head diameter. These results are in agreement with those obtained by (Roe and Cornforth, 2000) that showed combined application of organic and inorganic fertilizer increase head height and head diameter growth of cabbage plants at certain level but decreases the head quality. Subhan (2008) carried out an experiment on cabbage and observed that application of $15 \mathrm{t} \mathrm{ha}^{-1} \mathrm{FYM}$ with $200 \mathrm{~kg} \mathrm{~N} \mathrm{ha}{ }^{-1}$ increased head diameter $(15.87 \mathrm{~cm})$ after planting.

\subsection{Shoot Mass}

Analysis of data for both main effect of nitrogen and farmyard manure revealed non-significant $(\mathrm{P}>0.05)$ main effect on shoot mass and the interaction effect of both $\mathrm{N}$ and FYM had also non-significant $(\mathrm{P}>0.05)$ on this parameter.

\subsection{Untrimmed and Trimmed Head Weight}

4.6.1. Untrimmed Head Weight

The untrimmed weight of head was significantly $(\mathrm{P}<0.001)$ influenced by the application of different levels of nitrogen and farmyard manure nutrients and interaction effect of both $\mathrm{N}$ and FYM on head growth character of Chinese cabbage (Appendix Table 7).

Nitrogen and FYM had a significance $(\mathrm{P}<0.001)$ interaction effect on mean head weight $($ Table 8$)$. A summary of the analysis of variance determining the effect of different Nitrogen fertilizers and Farmyard manure rates on untrimmed and trimmed head weight of cabbage indicates that head weight responded differently. Application of the highest dose of Nitrogen fertilizer $\left(235 \mathrm{~kg} \mathrm{ha}^{-1}\right)$ with the dose of organic manure $\left(6 \mathrm{t} \mathrm{ha}^{-1}\right)$ produced a comfortable highest untrimmed head weight $(2296.67 \mathrm{~g})$ of cabbage which remained far with the untreated treatment. In this parameter the least mean untrimmed head weight $(883.33 \mathrm{~g})$ was recorded for the control and treatments received $294 \mathrm{~kg} \mathrm{~N}+10 \mathrm{t} \mathrm{FYM} \mathrm{ha}{ }^{-1}$. Meaning, application of the highest dose of organic manure $\left(10\right.$ ton $\left.^{-1} \mathrm{~h}^{-1}\right)$ in combination with Nitrogen $\left(294 \mathrm{~kg} \mathrm{~N} \mathrm{ha}^{-1}\right)$ caused a reduction in head weight compared with application of 6 ton $\mathrm{ha}^{-1}$ organic manure in combination with $235 \mathrm{~kg}$ nitrogen fertilizer ha ${ }^{-1}$ (Table 8). The result indicates that unbalanced nutrient application due to toxicity or in efficiency leads to decrease in the head mass. In general our result revealed that treatment combinations with Nitrogen and Farmyard manure fertilizers were recorded significantly different higher cabbage head weight over the control. Gupta (1987) reported maximum untrimmed head weight $(2220 \mathrm{~g})$ of cabbage is obtained at $150 \mathrm{~kg} \mathrm{ha}^{-1} \mathrm{~N}$ and $20 \mathrm{t} \mathrm{ha}{ }^{-1} \mathrm{FYM}$. In his experiment the maximum yields from $150 \mathrm{~kg} \mathrm{ha}^{-1} \mathrm{~N}$ and $20 \mathrm{tha}^{-1} \mathrm{FYM}$ were attributed mainly to increase in head mass. Preece and Read (2005) also reported increases in untrimmed head mass (1537) yielded by the application of $200 \mathrm{~kg} \mathrm{ha}^{-1} \mathrm{~N}$ in combination of $15 \mathrm{t} \mathrm{ha}^{-1}$ FYM beyond which there was a reduction in yield and head weight.

Table 11. Interaction Effect of $\mathrm{N}$ and $\mathrm{M}$ on Head Weight of Untrimmed of Head Cabbage (g/head)

\begin{tabular}{lccccc}
\hline Manure $($ ton ha & -1 $)$ & \multicolumn{5}{c}{ Nitrogen $\left(\mathrm{kg} \mathrm{ha}^{-1}\right)$} \\
\cline { 2 - 5 } 0 & 0 & 59 & 119 & 235 & 294 \\
3 & $883.33^{\mathrm{j}}$ & $1323.33^{\mathrm{h}}$ & $1483.33^{\mathrm{efg}}$ & $1660^{\mathrm{d}}$ & $1486.67^{\mathrm{efg}}$ \\
6 & $1163.33^{\mathrm{j}}$ & $1480^{\mathrm{efg}}$ & $1766.67^{\mathrm{c}}$ & $1576.67^{\mathrm{de}}$ & $1616.67^{\mathrm{d}}$ \\
10 & $1320^{\mathrm{j}}$ & $1440^{\mathrm{fg}}$ & $1610^{\mathrm{d}}$ & $2296.67^{\mathrm{a}}$ & $1620^{\mathrm{d}}$ \\
LSD $(0.05)=102.61 ; \mathrm{CV}(\%)=4.13$ & $1386.67^{\mathrm{gh}}$ & $1650^{\mathrm{d}}$ & $1506.67^{\mathrm{ef}}$ & $1946.67^{\mathrm{b}}$ & $883.33^{\mathrm{j}}$ \\
\hline
\end{tabular}

\subsubsection{Trimmed Head Weight}

Application of nitrogen and farmyard manure showed significantly different $(\mathrm{P}<0.001)$ main effect on trimmed head weight of head cabbage. Interaction effect of $\mathrm{N}$ and FYM also showed significantly different $(\mathrm{P}<0.001)$ on trimmed head weight of head cabbage plant as like the untrimmed head weight of the head cabbage.

Similarly like untrimmed head weight our ANOVA result the addition of Nitrogen and FYM in combination had a significance $(\mathrm{P}<0.001)$ interaction effect on mean trimmed head weight (Table 9$)$. A summary of the analysis of variance determining the effect of different Nitrogen fertilizers and Farmyard manure rates on trimmed head weight of cabbage indicates that head weight responded differently. Application of the highest dose of Nitrogen fertilizer $\left(235 \mathrm{~kg} \mathrm{ha}^{-1}\right)$ with the highest dose of organic manure $\left(6 \mathrm{tha}^{-1}\right)$ recorded a comfortable highest trimmed head weight $(1766.67 \mathrm{~g})$ of cabbage which remained far with the control and over fertilized treatment. In this parameter the least mean trimmed head weight $(260 \mathrm{~g}$ and $313.33 \mathrm{~g})$ was recorded for the treatments received $294 \mathrm{~kg} \mathrm{~N}+10 \mathrm{t} \mathrm{FYM} \mathrm{ha}^{-1}$ and control treatment respectively. Similarly as the untrimmed head weight, application of the highest dose of organic manure $\left(10\right.$ ton $\left.^{\mathrm{ha}^{-1}}\right)$ in combination with highest Nitrogen $\left(294 \mathrm{~kg} \mathrm{~N} \mathrm{ha}^{-1}\right)$ caused a reduction in head weight compared with application of $6 \mathrm{t} \mathrm{FYM} \mathrm{ha}{ }^{-1}+235 \mathrm{~kg} \mathrm{~N} \mathrm{ha}^{-1}$ (Table 9.). In general our result revealed that treatment combinations with Nitrogen and Farmyard manure fertilizers were recorded significantly higher cabbage net head weight over the control and over fertilized treatment. This result is in line with the results of Rincon et al. (1998) who found that increased N and FYM 
increase the weight of head cabbage. Similarly also observed that application of $200 \mathrm{~kg} \mathrm{~N}+15 \mathrm{t} \mathrm{FYM} \mathrm{ha}^{-1}$ resulted significantly high average trimmed weight of head cabbage as compared to the average weight of head from the control.

Table 12.Interaction Effect of $\mathrm{N}$ and $\mathrm{M}$ on Head Weight of Trimmed of Head Cabbage $\quad(\mathrm{g} / \mathrm{head})$

\begin{tabular}{|c|c|c|c|c|c|}
\hline \multirow[t]{2}{*}{ Manure $\left(\mathrm{t} \mathrm{ha}^{-1}\right)$} & \multicolumn{5}{|c|}{ Nitrogen $\left(\mathrm{kg} \mathrm{ha}^{-1}\right)$} \\
\hline & 0 & 59 & 119 & 235 & 294 \\
\hline 0 & $313.33^{\mathrm{k}}$ & $793.33^{\text {ghi }}$ & $933.33^{\mathrm{ef}}$ & $1140^{\mathrm{cd}}$ & $613.67^{j}$ \\
\hline 3 & $633.33^{j}$ & $956.67^{\mathrm{ef}}$ & $1250^{\mathrm{c}}$ & $1016.67^{\mathrm{de}}$ & $700^{\mathrm{ij}}$ \\
\hline 6 & $790^{\mathrm{hi}}$ & $933.33^{\text {efg }}$ & $1056.67^{\mathrm{de}}$ & $1766.67^{\mathrm{a}}$ & $616.67^{\mathrm{j}}$ \\
\hline 10 & $873.33^{\text {fgh }}$ & $1120^{\mathrm{cd}}$ & $1000^{\text {def }}$ & $1456.67^{\mathrm{b}}$ & $260^{\mathrm{k}}$ \\
\hline
\end{tabular}

$\operatorname{LSD}(0.05)=142.59 ; \mathrm{CV}(\%)=9.47$

Nitrogen fertilizers above $235 \mathrm{~kg} \mathrm{~N}$ alone, or in combination of organic fertilizers, did not increased significant marketable head weights. This variation was due to the availability of nutrients especially nitrogen and potassium and could be due to the improvement of soil water holding capacity as mentioned by Roe and Cornforth (2000). The reason suggested for such a response was that nitrogen and FYM which is a source of organic matter significantly increased growth parameters, which in return synthesized more plant metabolites thereby increasing yield. That means as the rate of nitrogen and FYM increases to certain level the mass of the head increases.

The studies carried out by Tei et al. (2000) on head cabbage showed that increasing FYM fertilizer level to $15 \mathrm{t} \mathrm{ha}^{-1}$ and Nitrogen fertilizer to $250 \mathrm{~kg} \mathrm{ha}^{-1}$ increased its net head mass value. A research conducted by White and Forbes (2007) on head cabbage applied manure fertilizer at different levels $\left(0,5,10\right.$ and $\left.20 \mathrm{t} \mathrm{FYM} \mathrm{ha}^{-1}\right)$ and Nitrogen fertilizer levels $(50,100,150,200)$ for two cabbage cultivars and estimated manure fertilizer rate to obtain maximum marketable head weight $(1780 \mathrm{~g})$ at about $10 \mathrm{t} \mathrm{FYM} \mathrm{ha}^{-1}$ with $150 \mathrm{~kg} \mathrm{~N}^{-1}$ for both cultivars. Furthermore, organic manure activates many species of living organisms, which release phytohormones and may stimulate the plant growth and absorption of nutrients. Such organisms need nitrogen for multiplication. This is the reason that the use of organic manure with inorganic fertilizer showed a beneficial effect on both growth and yield.

\subsection{Yield with Wrapper}

The analysis of variance revealed that the main effects of nitrogen and farmyard manure had highly significant different $(\mathrm{P}<0.001)$ on main effects and interaction response of yield with wrapper (Appendix Table 7). A summary of the analysis of variance determining the interaction effect of different Nitrogen fertilizer levels and Farmyard manure rates on yield with wrapper of cabbage indicates that significantly different $(\mathrm{P}<0.001)$ effect (Table 10.). Application rate of Nitrogen fertilizer $\left(235 \mathrm{~kg} \mathrm{ha}^{-1}\right)$ with the combination dose of FYM $\left(6 \mathrm{t} \mathrm{ha}^{-1}\right)$ produced a comfortable maximum $\left(107.47 \mathrm{t} \mathrm{ha}^{-1}\right)$ yield with wrapper head cabbage. However, application of the highest $\left(10 \mathrm{t} \mathrm{ha}^{-1}\right)$ dose of FYM in combination with Nitrogen $\left(294 \mathrm{~kg} \mathrm{~N} \mathrm{ha}^{-1}\right)$ caused a reduction in yield $\left(100.44 \mathrm{t} \mathrm{ha}^{-1}\right)$ compared with application rate of $6 \mathrm{t} \mathrm{ha}^{-1}$ organic manure and $235 \mathrm{~kg}$ nitrogen ha ${ }^{-1}$. All the treatment combinations with Nitrogen and Farmyard manure fertilizers were recorded significantly higher yield with wrapper over the control. Our ANOVA result also revealed that the addition of Nitrogen fertilizers above $235 \mathrm{~kg} \mathrm{~N} \mathrm{ha}^{-1}$ alone, or in combination of FYM did not increased significant yields. The yield was reduced due to the application of nutrients above $235 \mathrm{~kg} \mathrm{~N} \mathrm{ha}^{-1}$ alone and in combination with 6t FYM ha ${ }^{-1}$. In the study the least yield $\left(34.82 \mathrm{t} \mathrm{ha}^{-1}\right)$ was recorded for the control treatment.

Table 13.Interaction Effect of $\mathrm{N}$ and $\mathrm{M}$ on Yield with Rapper of Head Cabbage (ton/ha)

\begin{tabular}{llllll} 
Manure $\left(\mathrm{t} \mathrm{ha}^{-1}\right)$ & \multicolumn{5}{c}{ Nitrogen $\left(\mathrm{kg} \mathrm{ha}^{-1}\right)$} \\
\cline { 2 - 5 } 0 & 0 & 59 & 119 & 235 & 294 \\
3 & $34.82^{\mathrm{p}}$ & $58.76^{\mathrm{lm}}$ & $72.0 .05^{\mathrm{hi}}$ & $76.69^{\mathrm{fg}}$ & $78.94^{\mathrm{fg}}$ \\
6 & $42.73^{\mathrm{o}}$ & $62.24^{\mathrm{kl}}$ & $80.70^{\mathrm{ef}}$ & $87.89^{\mathrm{c}}$ & $83.3^{\mathrm{de}}$ \\
10 & $50.2^{\mathrm{n}}$ & $64.86^{\mathrm{jk}}$ & $88.92^{\mathrm{c}}$ & $107.47^{\mathrm{a}}$ & $85.65^{\mathrm{cd}}$ \\
& $56.28^{\mathrm{m}}$ & $68.03^{\mathrm{ij}}$ & $96.6 .81^{\mathrm{b}}$ & $100.44^{\mathrm{b}}$ & $75.3^{\mathrm{gh}}$
\end{tabular}

$\operatorname{LSD}(0.05)=4.25 ; \mathrm{CV}(\%)=3.49$

There was a significant effect of different doses of nitrogen and FYM on yield with wrapper of cabbage. This might be due to the fact that nitrogen supplied readily and the supplied manure also releases available plant nutrients for vigorous growths slowly. Yield with wrapper was reduced due to the application of nutrients above $235 \mathrm{~kg} \mathrm{~N} \mathrm{ha}^{-1}$ and 6t FYM ha ${ }^{-1}$ that do not allow the plant grow effectively. Gupta (1987) reported that the maximum head with wrapper yield was recorded in treatment receiving $120 \mathrm{~kg} \mathrm{~N}, 90 \mathrm{~kg} \mathrm{P}$ and $15 \mathrm{t} \mathrm{FYM} \mathrm{ha}{ }^{-1}$ in cabbage. The significant increase in yield with wrapper in response to the increased nitrogen and organic fertilizer levels might be attributed to the positive role of balanced nutrients in the physiology of the plant in cell elongation and enhancing above ground vegetative growth, photosynthesis, and ultimate partitioning of photosynthate to the heads development. Our result is in line with that of Roe and Cornforth (2000) who reported 
that higher dose $\left(200 \mathrm{~kg} \mathrm{~N}^{-1}\right)$ of nitrogen and $25 \mathrm{t} \mathrm{ha}^{-1}$ FYM produced higher wrapper head yield $\left(78.56 \mathrm{t} \mathrm{ha}^{-1}\right)$ than lower doses of the nutrient. kumar et al. (2002) also reported that the maximum wrapper head yield (81 $\mathrm{t}^{-}$ $\left.{ }^{1}\right)$ was recorded in treatment receiving $250 \mathrm{~kg} \mathrm{~N} \mathrm{ha}^{-1}$ and $20 \mathrm{t} \mathrm{ha}^{-1} \mathrm{FYM}$ in cabbage.

Moreover the application of FYM and Nitrogen significantly increased all yield and yield related components. This ability of combined use of FYM and Nitrogen to significantly influence this character may probably be due to the fact that combined use supplies nitrogen phosphorous and micro nutrients to the crop. More so, FYM has high organic carbon content and other macro and micro nutrients such as $\mathrm{N}, \mathrm{P}, \mathrm{K}, \mathrm{Ca}, \mathrm{Mg}$ and $\mathrm{Fe}$ which are essential for good crop growth and nitrogen has a tendency to supply readily available nutrient for the crop. These results are in agreement with those obtained by Din et al. (2007). Stamatiadis et al. (2009) result revealed that highest cabbage head yield $\left(62.3 \mathrm{t} \mathrm{ha}^{-1}\right)$ produced by application of FYM at rate of $10 \mathrm{t} \mathrm{ha}^{-1}$ with $250 \mathrm{~kg} \mathrm{~N}^{-1}$ respectively.

\subsection{Yield without Wrapper}

Similar to wrapper yield, the yields of cabbage without wrapper were positively affected by both the Nitrogen and FYM (Appendix Table 7). All treatments received nitrogen had significantly $(\mathrm{P}<0.001)$ different main and interaction effect on yield without Wrapper. The ANOVA result revealed that highest head yield without wrapper per hectare of $72.36 \mathrm{t} \mathrm{ha}^{-1}$ were observed in the $6 \mathrm{t} \mathrm{ha}^{-1}$ Farmyard manure and $235 \mathrm{~kg} \mathrm{ha}^{-1}$ fertilizer combination and the least yield of $19.15 \mathrm{t} \mathrm{ha}^{-1}$ were recorded in the untreated control treatment (Table 11). The highest combination of $10 \mathrm{t} \mathrm{ha}^{-1}$ farmyard manure and $294 \mathrm{~kg} \mathrm{ha}^{-1}$ nitrogen gave a yield advantage of $26.83 \%$ over the control. The interaction thus showed response to FYM was more at higher rates of $\mathrm{N}$ application. The farmyard manure applied at $6 \mathrm{t} \mathrm{ha}^{-1}$ combined with $235 \mathrm{~kg} \mathrm{ha}^{-1}$ fertilizer was just enough to satisfy the yield requirements of cabbage plant in this study. This was evident in the significant yield experienced in the other treatments. This result is in agreement with Preece and Read (2005) that work their research on head cabbage reported, increases in yield up to $200 \mathrm{~kg} \mathrm{~N} \mathrm{ha}^{-1}$ and $20 \mathrm{t} \mathrm{FYM} \mathrm{ha}^{-1}$, beyond which there was a reduction in yield. For the current experiment higher yields at higher nitrogen and FYM doses could be attributed to great head height, diameter and yield obtained at nitrogen doses $\left(235 \mathrm{~kg} \mathrm{ha}^{-1}\right)$ and FYM doses $\left(6 \mathrm{t} \mathrm{ha}^{-1}\right)$. This result is corroborated by Olaniyi and Ojetayo (2011) who reported that marketable head yield was increased in response to increased rate of nitrogen fertilizer $150 \mathrm{~kg} \mathrm{ha}^{-1}$ after which it reduced.

The yield from the experiment was in agreement with the report of Murwira and Kirchman (2007) who found that increased yield $\left(65.43 \mathrm{t} \mathrm{ha}^{-1}\right)$ of cabbage through the combination of farmyard manure $\left(10 \mathrm{t} \mathrm{ha}^{-1}\right)$ and Nitrogen $\left(200 \mathrm{~kg} \mathrm{ha}^{-1}\right)$ fertilizer and the findings of Sarker et al. (2003) who reported that the best way to increase cabbage yield was by the combination of organic wastes and nitrogen fertilizer. Aditya (2003) reported that highest, $\left(60 \mathrm{tha}^{-1}\right)$ yield of cabbage was obtained by the application of $375 \mathrm{~kg} \mathrm{~N}^{-1}$ along with FYM at the rate of $10 \mathrm{tha}^{-1}$. White and Forbes (2007) also worked with cabbage in USA to find out the effect of nitrogen and FYM on the growth and yield of cabbage. They concluded that cabbage yield responded positive to N and FYM combination application up to the level of $308 \mathrm{~kg} \mathrm{ha}^{-1}$ and $15 \mathrm{t} \mathrm{FYM} \mathrm{ha-1}$. More than this dose resulted reduced head yield proportionately.

The application of $\mathrm{N}$ and FYM significantly increased all yield up to certain level, the result is obtained reasonably because of combined utilization significantly influence yield and yield related characters at all levels due to the fact that FYM supplies both macro and micro elements and also inorganic nitrogen have an ability of easily useable by the plant. Similarly the plant food produced by organic manures is as good as that supplied by nitrogen fertilizers. But there is an important difference in that manure is given in large quantity when compared with nitrogen fertilizers and the organic manure gets decomposed very slowly and supply the plant with food in small doses while the nitrogen supply the necessary requirements all at once in a soluble form. An experiment carried out by Samant et al. (2003) to investigate the balanced N fertilizer and FYM for cabbage using application rate of $\left(40,60,80,100,140,160,180\right.$ and $\left.200 \mathrm{~kg} \mathrm{~N} \mathrm{ha}^{-1}\right)$ and $\left(5,10,15,20,25,30\right.$ and $\left.35 \mathrm{t} \mathrm{ha}^{-1}\right)$ respectively, on the marketable head yield of cabbage showed that yield increased to $49.83 \mathrm{t} \mathrm{ha}^{-1}$ with increasing rates of $\mathrm{N}$ to $180 \mathrm{~kg} \mathrm{ha}^{-1}$ and $25 \mathrm{t} \mathrm{FYM} \mathrm{ha}{ }^{-1}$. Yield decreased with the further increase in $\mathrm{N}$ rates and FYM rates. Generally there was an increasing trend in the yield without wrapper parameter with the increasing in the rate of combined application of $\mathrm{N}\left(0,59,119\right.$ and $\left.235 \mathrm{~kg} \mathrm{ha}^{-1}\right)$ with FYM $\left(0,3\right.$ and $\left.6 \mathrm{t} \mathrm{ha}^{-1}\right)$.

Table 14.Interaction Effect of $\mathrm{N}$ and $\mathrm{M}$ on Yield with Out Rapper of Head Cabbage ( $\mathrm{t} / \mathrm{ha})$

\begin{tabular}{lccccc}
\hline \multirow{2}{*}{ Manure (ton ha $\left.^{-1}\right)$} & \multicolumn{4}{c}{ Nitrogen $\left(\mathrm{kg} \mathrm{ha}^{-1}\right)$} \\
\cline { 2 - 5 } 0 & 0 & 59 & 119 & 235 & 294 \\
\cline { 2 - 6 } 3 & $19.15^{\mathrm{n}}$ & $39.22^{\mathrm{jk}}$ & $48.46^{\mathrm{fgh}}$ & $53.92^{\mathrm{ef}}$ & $53.58^{\mathrm{efg}}$ \\
6 & $24.85^{\mathrm{m}}$ & $41.85^{\mathrm{ijk}}$ & $56.62^{\mathrm{cde}}$ & $59.65^{\mathrm{cd}}$ & $55.52^{\mathrm{de}}$ \\
10 & $31.53^{\mathrm{l}}$ & $43.17^{\mathrm{hij}}$ & $61.58^{\mathrm{bc}}$ & $71.36^{\mathrm{a}}$ & $57.08^{\mathrm{cde}}$ \\
& $36.38^{\mathrm{kl}}$ & $45.23^{\mathrm{hi}}$ & $61.88^{\mathrm{bc}}$ & $66.74^{\mathrm{ab}}$ & $48.30^{\mathrm{gh}}$
\end{tabular}

$\operatorname{LSD}(0.05)=5.48 \mathrm{CV}(\%)=6.8$

Organic manures are the main source of soil organic matter, which has a fundamental effect on physical and 
physiochemical properties of soil. Organic manures also are an important source of plant nutrients but contain relatively in small amounts, which are not readily available. On the other hand, inorganic fertilizer contains specific, higher, and readily available plant nutrients. So the combination of organic manures and inorganic fertilizers is likely to be more productive. A number of researches have been conducted to investigate the combined effect of organic manures and inorganic fertilizers. According to our result cabbage marketable head yield per hectare was significantly influenced by the application of farmyard manure, Nitrogen and their interaction. Both Nitrogen and organic fertilizer farmyard manure application had a pronounced effect on the yield and yield contributing characters of cabbage in the conducted experiment.

\subsection{Biomass Yield}

Both $\mathrm{N}$ and FYM had highly significantly $(\mathrm{P}<0.001)$ different main effects on the biomass yield of the head cabbage (Appendix Table 7). What is more, there was also a highly significant $(p<0.001)$ interaction effect of the two nutrients on this parameter of the plant.

As the summary of ANOVA revealed (Table 12) both nitrogen and farmyard manure have significantly interact at $\mathrm{P}<0.001$. The results showed that all nitrogen and farmyard manure treatments significantly increased the biomass yield of cabbage crop on each treatment. The maximum biomass yield of $107.47 \mathrm{t} \mathrm{ha}^{-1}$ was obtained in treatment receiving $\mathrm{N}$ from UREA of $235 \mathrm{~kg} \mathrm{ha}^{-1}$ and FYM of $6 \mathrm{t} \mathrm{ha}^{-1}$ combination and followed by those receiving $235 \mathrm{~kg} \mathrm{~N}$ with an addition of $10 \mathrm{t} \mathrm{FYM} \mathrm{ha}^{-1}$ yielding $100.44 \mathrm{t} \mathrm{ha}^{-1}$ biomass yield. But the biomass yield was minimum $\left(34.21 \mathrm{ha}^{-1}\right)$ in the control treatment. Consistent biomass yield increment was observed at control, 59 and $119 \mathrm{~kg} \mathrm{~N} \mathrm{ha}^{-1}$ with all rates of Farmyard manure. Vachani and Patel (1991) also reported that increase in biomass yield with increase in $\mathrm{N}$ up to $200 \mathrm{~kg} \mathrm{ha}^{-1}$ significantly augmented leafy yield of head cabbage.

These findings are also in agreement with Haque (2000) who reported significant increases in cabbage head yields with addition of FYM to nitrogen fertilizers as compared to control treatment. The interaction of different rates of recommended dose of nitrogen fertilizers with various rates of farmyard manures had a significant effect on biological yield (Table 12). Generally it was observed that treatments that received both FYM and inorganic nitrogen fertilizer produced plants with more biomass yield as compared to plants in unfertilized plot. Chowdahury et al. (2002) also reported that plants treated with both organic and manure was significantly higher in biomass. It is also interesting to note that the least above ground biomass was recorded with absolute control treatment. Generally the amount the trend of biomass increased slightly as N and FYM level increased from 0 to $235 \mathrm{~kg} \mathrm{ha}^{-1}$ and 0 to $6 \mathrm{tha}^{-1}$ respectively (Table 13) in the study area. These results suggest that $\mathrm{N}$ and FYM have a potential of increasing biomass yield which will then be incorporated into the soil for the benefit of the subsequent and readily available crop. However higher level of $\mathrm{N}(294 \mathrm{~kg})$ and FYM (10t) is not desirable as it causes biomass yield decline. The increase in the uptake of nutrients by cabbage head with application of $\mathrm{N}$ along with FYM is obvious as it is considered as a storehouse of plant nutrients, which provide optimum nutrients for crop and yields highest biomass. The finding of Kaur et al. (2005) concluded in his research work that excessive use of in organic and organic manure causes reduction in biomass of cabbage crop. Table 15.Interaction Effect of $\mathrm{N}$ and $\mathrm{M}$ on Biomass yield of Head Cabbage (ton ha ${ }^{-1}$ )

\begin{tabular}{lccccc}
\hline Manure & $(\mathrm{t}$ & \multicolumn{5}{c}{ Nitrogen $\left(\mathrm{kg} \mathrm{ha}^{-1}\right)$} \\
\cline { 2 - 5 } $\left.\mathrm{ha}^{-1}\right)$ & 0 & 59 & 119 & 235 \\
0 & $34.2^{\mathrm{p}}$ & $58.76^{\mathrm{lm}}$ & $72.0^{\mathrm{hi}}$ & $76.69^{\mathrm{fg}}$ & $78.94^{\mathrm{fg}}$ \\
3 & $42.7^{\mathrm{o}}$ & $62.24^{\mathrm{kl}}$ & $80.7^{\mathrm{ef}}$ & $87.89^{\mathrm{c}}$ & $83.33^{\mathrm{de}}$ \\
6 & $50.2^{\mathrm{n}}$ & $64.86^{\mathrm{jk}}$ & $88.9^{\mathrm{c}}$ & $107.4^{\mathrm{a}}$ & $85.65^{\mathrm{cd}}$ \\
\cline { 2 - 6 } 10 & $56.3^{\mathrm{m}}$ & $68.03^{\mathrm{ij}}$ & $96.7^{\mathrm{b}}$ & $100.4^{\mathrm{b}}$ & $75.29^{\mathrm{gh}}$ \\
\hline
\end{tabular}

$\operatorname{LSD}(0.05)=42.48 ; \mathrm{CV}(\%)=3.5$

\subsection{Correlation Analysis}

Correlation coefficient values ( $r$ ) computed to display the relationships between and within agronomic parameters of head yield of cabbage are shown in Appendix Table 1. The correlation values explain the apparent association of the nutrient parameters and yield components with each other and clearly indicated the magnitude and direction of the association and relationships. Among the several yield components, days to head initiation, maturity and days to harvesting were negatively correlated with the nitrogen and farmyard manure concentration and uptake of the plant. This means as the rate uptake of the plant increases the days to head initiation, maturity and harvesting inversely decreased.

In another case yield parameters of yield with wrapper, yield without wrapper, biological yield, plant height and number of expanded leafs were highly positively correlated with nitrogen and farmyard manure concentration and uptake of the plant. Thus, the result implied that increased $\mathrm{N}$ and FYM uptake and its concentration in the plant maximize the indicated parameters. This agreed with the physiological aspect of the nutrient imposed on plant growth and development (Mbatha. 2008). Similarly head height, head diameter, head weight untrimmed, trimmed and harvest index responded positively to the concentration of nitrogen and 
farmyard manure but not significantly. This implies that increase in $\mathrm{N}$ and FYM increases for the mentioned parameter, but not significantly correlated.

The correlation analysis between total net yield $\left(\mathrm{t} \mathrm{ha}^{-1}\right)$ and yield and growth characters indicated that, net yield was positively correlated with mean plant height $\left(\mathrm{r}=0.71^{* *}\right)$, number of leafs $\left(\mathrm{r}=0.65^{* *}\right)$, head height $\left(\mathrm{r}=0.65^{* *}\right)$, head diameter $\left(\mathrm{r}=0.68^{* *}\right)$, head weight untrimmed $\left(0.76^{* *}\right)$, head weight trimmed $(0.62 * *)$, yield with wrapper $\left(0.96^{* *}\right)$ and biological yield $\left(0.96^{* *}\right)$ were strongly positively correlated with yield without wrapper or net head yield. However Mean shoot mass and harvest index are positively correlated, they are poorly correlated with the net yield, but days to head initiation $\left(\mathrm{r}=-0.77^{* *}\right)$, days to maturity $\left(\mathrm{r}=-0.73^{* *}\right)$ and days to harvesting $\left(\mathrm{r}=-0.57^{* *}\right)$ were highly negatively correlated to the total net head yield. Therefore Total fresh yield were significantly and positively correlated with all growth, yield and yield related traits with the exception of shoot mass. This implies that improving any of these parameters may lead to the improvement in yield. Generally, the correlation coefficients indicated in Appendix Table 8 clearly explained the pattern of interrelationship among the yield and yield attributes considered in the experiment.

\subsection{Partial Budget Analysis}

In this study, the costs of Nitrogen fertilizer and labor cost for transplanting and fertilizer application varied while other costs were constant for each treatment. In order to recommend the present result for end users, it is necessary to estimate the minimum rate of return acceptable to farmers in the recommendation domain. Based on partial budget analysis, the net benefit accrued from the experiment ranged from nitrogen application alone is birr 93498 to 112603 per hectare (Appendix Table 2.) compared with non-application of nutrients which is birr 45135 per hectare. For the farmyard manure treatments alone net benefit ranged from birr 58774 to 76764 per hectare benefit. This is an indication of the level of profitability of the animal manure treatments. The marginal rate of returns, which determines the acceptability of any treatment shows that treatments that receiving $235 \mathrm{~kg}$ $\mathrm{N} \mathrm{ha}^{-1}$ in combination with $6 \mathrm{t} \mathrm{ha}^{-1}$ of FYM yielded good results of $2535.31 \%$ marginal revenue. However, the marginal rate of returns for the Nitrogen fertilizer alone was higher than those for the farmyard manure. All in all the highest net benefit 176058 birr was obtained from treatment combination of $235 \mathrm{~kg} \mathrm{~N}^{-1}$ with $6 \mathrm{t} \mathrm{ha}^{-1} \mathrm{FYM}^{-1}$ with a marginal rate of return $2535.31 \%$ but the lowest net benefit 76764 birr was obtained from the treatment combination of $59 \mathrm{~kg} \mathrm{~N}^{-1}$ with $6 \mathrm{tha}^{-1} \mathrm{FYM}$ with a marginal rate of return of $71.16 \%$ only in one growing season (Appendix Table 9). This means that for every 1.00 birr invested for $235 \mathrm{~kg} \mathrm{~N} \mathrm{ha}^{-1}$ with $6 \mathrm{t} \mathrm{ha}^{-1}$ farmyard manure input and its application in the field, farmers can expect to recover the 1.00 birr and obtain an additional 25.35 birr. Therefore the most attractive rates for producers with low cost of production and higher benefits in this case were $235 \mathrm{~kg} \mathrm{~N} \mathrm{ha}^{-1}$ with $6 \mathrm{t} \mathrm{ha}^{-1}$ farmyard manure combination. The marketable head yield was adjusted by $10 \%$ adjustment coefficient and the marginal rate of return (MRR) and net benefits are calculated by current fertilizer (Urea) was $8.50 \mathrm{~kg}^{-1}$ and field price of cabbage was 3.00 birr kg-1.

\section{SUMMARY AND CONCLUSIONS}

The maximum yield achievement by crop relies on the application of the correct level of nutrients. In addition, especially for production of crop, the effect of fertilizer levels is important. Therefore, the present study was initiated to assess the effects of different levels of nitrogen and farmyard manure on yield and yield components of cabbage. Accordingly, five levels of $\mathrm{N}$ and four levels of FYM fertilizer were evaluated at Bore, southern Ethiopia in $5 \times 4$ factorial arrangements using randomized complete block design with three replications on a plot size of $3.6 \mathrm{~m} \mathrm{X} 3 \mathrm{~m}$ per treatment unit. Cultivation aspects such as nutrient requirements are vital in maximization of cabbage head yields. It is therefore, important for the end user to determine the best combination of optimum nitrogen and organic manure (FYM) levels. Incorporation of FYM and nitrogenous fertilizer will improve yields of head cabbage.

Applied $\mathrm{N}$ fertilizer levels revealed highly significant differences $(\mathrm{P}<0.001)$ on plant height, number of expanded true leafs, days to head initiation, days to maturity, average head height, head diameter, days to harvesting, untrimmed head weight, trimmed head weight, yield with wrapper, yield without wrapper and biological yield. But field stand count, shoot mass and harvest index were not influenced by the nitrogen fertilizer. FYM fertilizer application levels also revealed highly significant differences $(\mathrm{P}<0.001)$ on plant height, number of expanded true leafs, days to head initiation, days to maturity, average head height, head diameter, days to harvesting, untrimmed head weight, trimmed head weight, yield with wrapper, yield without wrapper and biological yield. Similarly like nitrogen, FYM application did not influenced field stand count, shoot mass and harvest index of head cabbage.

The interaction effect between $\mathrm{N}$ and FYM fertilizer application rates highly significantly $(\mathrm{P}<0.001)$ influenced plant height, number of expanded true leafs, days to head initiation, days to maturity, average head height, head diameter, days to harvesting, untrimmed head weight, trimmed head weight, yield with wrapper, yield without wrapper and biological yield per hectare. Field stand count, shoot mass and harvest index didn't show significant difference $(\mathrm{p}>0.05)$ because of the application of $\mathrm{N}$ and FYM application rates. Highest 
untrimmed head and trimmed head weight was produced under all the $\mathrm{N}$ and FYM fertilizer rates. The untrimmed head weight $(1870 \mathrm{~g}$ and $1650 \mathrm{~g})$ was obtained by application of $\mathrm{N}$ and FYM fertilizer at a rate of 235 $\mathrm{kg} \mathrm{N} \mathrm{ha}^{-1}$ and $6 \mathrm{t} \mathrm{ha}^{-1}$ respectively. Similarly the trimmed head weight $(1340 \mathrm{~g}$ and $1030 \mathrm{~kg})$ was obtained by application of $\mathrm{N}$ and FYM fertilizer at a rate of $235 \mathrm{~kg} \mathrm{~N} \mathrm{ha}^{-1}$ and $6 \mathrm{t} \mathrm{ha}^{-1}$, respectively. In a similar way the interaction effect revealed highest untrimmed head weight $(2290 \mathrm{~kg})$ obtained with treatment combinations of $235 \mathrm{~kg} \mathrm{~N} \mathrm{ha}{ }^{-1}+6 \mathrm{tha}^{-1}$ over the control plot. As to the interaction effect of nitrogen and FYM on net or trimmed head weight highest result $(1760 \mathrm{~kg})$ obtained with treatment combinations of $235 \mathrm{~kg} \mathrm{~N} \mathrm{ha}^{-1}+6 \mathrm{t}^{-1}$ over the control plot. It can be concluded that different Nitrogen, FYM rate and their interaction have remarkable effect on yield of cabbage. From this study it is found that, highest head yield without wrapper per hectare of $72.36 \mathrm{t}$ $\mathrm{ha}^{-1}$ was observed in the combination treatment of $6 \mathrm{t} \mathrm{ha}^{-1} \mathrm{FYM}+235 \mathrm{~kg} \mathrm{~N} \mathrm{ha}^{-1}$ fertilizer and the least yield of $19.15 \mathrm{t} \mathrm{ha}^{-1}$ were observed in the untreated control. Therefore, these treatment combinations appeared promising for cabbage production under the study area. Our result of the study revealed that the combined application of Nitrogen fertilization and farmyard manure resulted in better performance in terms of improving total net head cabbage yield.

Based on partial budget analysis the highest net benefit 176058 birr was obtained from treatment combinations of $235 \mathrm{~kg} \mathrm{~N} \mathrm{ha}^{-1}$ with $6 \mathrm{t} \mathrm{ha}^{-1}$ with a marginal rate of return of $2535.31 \%$. Therefore the most attractive rates for the producers with low cost of production and higher benefits in this case were treatment combination of $235 \mathrm{~kg} \mathrm{~N} \mathrm{ha}^{-1}$ with $6 \mathrm{t} \mathrm{ha}^{-1}$. However, as this is a one location and one season experiment the experiment has to be repeated over seasons and locations with consideration of additional varieties, soil type and economic feasibility to reach at convincing recommendation.

Mineral nitrogen from mineral solution fertilizers represents the easier available form of nitrogen compare recommended mineral fertilizers. Using organic manure plus inorganic solution fertilizers gave a significant effect on plant growth, heads yield, chemical constituents and mineral composition of broccoli. Organic manure enhances soil aggregation, aeration, water holding capacity and amended the root system by slow release flow of nutrients which in combination creates favorable conditions for root respiration, nutrients absorption, root and upper parts growth and yield quantity and quality. Organic manure increases the fertility and productivity of sandy soils. As far as the agronomic productivity is concerned, it would be difficult to make definite conclusion based on the research results of one season and one location. Therefore cabbage growers at Bore and surrounding area need to apply farmyard manure of 6 ton in combination with nitrogen at $235 \mathrm{~kg}$ per hectare, in order to maximize the yield of head cabbage on the soils of study area. Generally due to high cost of fertilizer in the market, cabbage growers can combine the farmyard manure and inorganic nitrogen to reduce cost and since organic FYM releases both major and minor nutrients, farmers should embark on the use of FYM for effective growth and yield since it's found in their areas.

\section{REFERENCES}

Aalbersberg, I.J. and Stolk, J.H. (2003). Descriptive list of varieties of vegetables for field cultivation 1994 (in Dutch). CPRO-DLO, Wageningen, the Netherlands. Pp: 259-260.

Aditya, D.K. (2003). Vegetable Production and Development in Bangladesh. Republic of Agricultural Research Project Phase II, BARC, BARI, AVRDC, Dhaka. Pp: 68-70.

Arisha, H.M.E., Gad, A.A. and Younes, S.E.(2003). Response of some cabbage cultivars to organic and mineral nitrogen fertilizer under sandy soil conditions. Zagazig Journal of Agricultural Research, 30: 75-99.

Archer, J. (1988). Crop Nutrition and Fertilizer Use. Second Edition. Farming Press Ltd. Wharfedaale Road, Ipswich, Suffolle.

Ashworth. (2002). Seed to Seed: Seed Saving and Growing Techniques for Vegetable Gardeners. New York: Seed Savers Exchange In, Pp: 54-68.

Baloch, M.A., Baloch, A.F., Baloch, G., Ansari A.H. and Qayyum, S.M. (2000). Growth and yield response of cabbage to different nitrogen and potassium fertilizer combination levels. Sarhad Journal of Agriculture 7: 63-66.

BARC (Bangladesh Agricultural Research Council). (1997). Fertilizer Recommendation Guide 1997. Bangladesh Agricultural Research Council, Farmgate, Dhaka. 196Pp.

Berhanu Debele. (1980). The physical criteria and their rating proposed for land evaluation in the highland region of Ethiopia. Land Use Planning and Regulatory Department, Ministry of Agriculture, Addis Ababa, Ethiopia.

Bhardwaj, M.L., Hardener, R. and Koul, B.L. (2000). Yield response and economics of organic sources of nutrient as substitute to inorganic sources in tomato (Lycopersicon esculentum), Okra (Hibiscus esculentus), Cabbage (Brassica oleracea var. capitata) and cauliflower (Brassica oleracea var. botrytis). Indian Journal of Agricultural Science; 70(10):653-656.

Bhuiyan, N.I. (2010). Application of integrated plant nutrition system (IPNS) in Agriculture- Bangladesh Experiences. Workshop on integrated plant nutrition system development and rural poverty alleviation, 18- 
20 September 2010. Bangkok, Thailand.

Brady, N.C. (2003). The Nature and Properties of Soil. Macmillan Publishing Company, New York and Collier Macmillan Publishers, London. 203Pp.

Bulluck, L.R., Brosius, M., Evanylo, G.K. and Ristaino J.B. (2002). Organic and Synthetic Fertility Amendments Influence Soil Microbial, Physical and Chemical Properties on Organic and Conventional Farms. Applied Soil Ecology, 19:147-160.

Bumb, B.L. and Baanate, C.A. (1996). The role of fertilizer in sustaining food security and Protecting the Environment. International Food Policy Research Institute, 5(3):36-38.

CSA (Central Statistics Agency). (2012). Agricultural Sample Survey. Report on Area and Production of Major Crops. Addis Ababa Ethiopia, 1:15-58.

Chand, S., Anwar, M. and Patra, D.D. (2006). Influence of long-term application of organic and inorganic fertilizer to build up soil fertility and nutrient uptake in mint mustard cropping sequence. Communications in Soil Science and Plant Analysis, 37: 63-76.

Chaubey, T., Srivastava, B.K., Singh, M., Chaubey, P.K and Rai, M. (2006). Influence of fertility levels and seasons on maturity and morphological traits of cabbage. Vegetable Science, 33(1):29-33.

Chowdhury, M.M.U., Anwar, M.N., Sarker, J.U., Firoj S.A. and Uddin, M.Z. (2002). Response of molybdenum and organic manure on the growth and yield of cabbage in the hily region. Bangladesh Journal of Agricultural Research, 23(4): 705-711.

CIMMYT (The International Maize and Wheat Improvement Center). (1988). From Agronomic Data to Farmers Recommendations: An Economics Training Manual. Completely Revised Edition. Mexico, D.F. ISBN 96861 27-18-6.

Ciszinsky, A.A. and Schester, S.J. (2001). Response of cabbage to insecticide schedule plant spacing and fertilizer rates. Journal of American Soil and Horticultural Science, 110(6):888-893.

Cottenie, A. (1980). Soil and plant testing as a base of fertilizer recommendations. Soils Bulletins, No. 38 , Pp.22. FAO, Rome.

Din, M., Qasim, M. and Alam, M. (2007). Effect of different levels of N, P and K on the growth and yield of cabbage. Journal of Agricultural Research, 45(2):171-176

Everaarts, A.P. and Moel, C.P. (2011). The effect of nitrogen and the method of application on yield and quality of white cabbage. European Journal of Agronomy, 45:203-211.

Farid, A.T., Rahman, K.H., Talukder, Shahidullah, M. and Islam M.S. (2008). Efficiency of poultry manure and cowdung alone combination with mineral fertilizers and the yield of cabbage. Bangladesh Journal of Agriculture, 23(1):157-165.

Felczynski, K., Adamicki, F. and Felczynska, A. (2004). Effect of different rates of nitrogen fertilization on the yield and storability of Chinese cabbage. Nowoski Warzywnicze, Pp: 55-56.

FSSA (Fertilizer Society of South Africa). (2003). The fertilizer handbook. Organic fertilizers 15th edition. Foskor Publisher, Lynwood Ridge, South Africa, 15:12-27.

Fisseha Gedamu. (1983). The effects of Alternative sources of organic fertilizers in increasing the yield of onions (Allium Cepa L.) A thesis (M.SC) presented to School of Graduate Studies of Addis Ababa University, Addis Ababa.

FAO (Food and Agriculture Organization). (2011). Quarterly Bulletin of Statistics. Food and Agricultural Organization of the United Nations. Rome Italy, 12:37-41.

Gontcharenko,V.E. (1999). The Effect of Crops Alternation As Well As Fertilization on Soil Productivity, Yield and Quality of Vegetables. Acta Horticulture, 371: 431 - 436.

Gupta, A. (1987). Effect of N and Irrigation on Cabbage Production. Indian Journal of Horticultural Science, 44:241-244.

Gulser, F. (2005). Effect of ammonium sulphate and urea on NO3- and NO2- accumulation nutrient contents and yield criteria in spinach. Scientia Horticulturae 106, 330-340.

Haque, M.O. (2000). Effects of different fertilizer management practices on the growth and yield of main and ratoon crop of cabbage. MSc Thesis, Department of Horticultural, Bangladesh Agricultural University, Mymensingh. pp96.

Haque, K.M.F. (2006). Yield and nutritional quality of cabbage as affected by nitrogen and phosphorus fertilization. Bangladesh Journal of Science. 41:41-46.

Hochmuth, R.C., Hochmuth, J. and Donley, M.E. (1999). Response of cabbage yields, head quality and leaf nutrient status and of second crop squash to poultry manure fertilization, Florida, 52:126-130.

Jackson, M.L. (1967). Soil Chemical Analysis. Prentice-Hall of India, New Delhi.

Jaiswal, N.K., Khare, Sharma, B.K. and Shrivastava, S.S. (2002). Effect of nitrogen levels, method of application and spacing on growth and productivity of cabbage. Advances in Horticulture, Forestry, 2: 158164.

Kamiyama, K.S., Fujiwara and Furahashi, H. (2005). Effect of successive application of cow manure compost on 
growth of crops and the chemical properties of the soil. Agricultural Research Institute of Kanagawa Prefecture, 136:31-42.

Kaur, K., Kapoor, K.K. and Gupta, A.P. (2005). Impact of organic manures with and without mineral fertilizers on soil chemical and biological properties under tropical conditions. Journal Plant Nutrition and Soil Science, 168: 117-122.

Khadir, G.A., Marazat, S.K. and Sadoun, S.A. (2002). Effect of different levels of urea fertilizers and plant spacing on growth and yield of cabbage. Dirasat, 16(9): 88-105.

Krezel, J. and Koota, E. (2004). The effect of nitrogen fertilization on yield and biological value of Chinese cabbage grown from seed growing for autumn harvest. Folia Universitatis Agriculturae Stetinensis Agriculture, 95:197-200.

Krupkin, P.L., Makrinova, M.A., Yaltonskii, Kilby, Ya and Yaltonsky, M.A. (2004). Effectiveness of lignin based fertilizers in Siberia Agrokhimiya, 12: 5364.

Kumar, M. and Rawat T.S. (2002). Effect of Nitrogen and Spacing on the Quality and Yield of Cabbage (Brassica Oleracea L. Var. Capitata). Agricultural Science Digestion, 22(2), 90- 92.

Lampkin, N.H. (2000). Organic farming. In:Padel $5^{\text {th }}$.editions. Soil sickness and soil fertility, Cab Publisher, Wallingford, USA.

Lander, Charles, H., David, M. and Klaus, A. (2008). "Nutrients available from Livestock Manure Relative to crop Growth Requirements", United States Department of Agriculture, Natural Resources Conservation Service. New York USA, 12:76-77.

Lawande, K.E., Bhore, D.P., Kale, P.N. and Patil, S.D. (2001). Effect of spacing, nitrogen phosphorus and potassium on yield and yield contributing characters of cabbage S. Maharashtra, Agricultural University, 11(2): 192-196.

Lesic, R., Borosic, J., Buturac, I., Herak-Custic, M., Poljak, M. and Romic, D. (2004). Povrcarstvo. Zrinskid Cakovec. Dhaka, 65-93.

Liu, W. and Li, S. (2003). Effects of Organic Nutrient Solution on Growth and Quality of Pak- Choi under Soilless Culture. Acta Horticulture, 6:139-144.

Lopandic, D., Zaric, D., Jevtic, S. and Lazic, B. (2007). The effect of nitrogen rates and application dates on cabbage yield. Proceedings of the first Balkan Symposium on Vegetables and Potatoes. Betgarde. Yugaslavia, 462: 595-598.

Magnusson, M. (2002). Mineral fertilizers and green mulch in head cabbage (Brassica pekinensisrupr): Effect on Nutrient Uptake, Yield and Internal Tip Burn. Soil Plant Science, 52:25-35.

Mallik, S.C. and Bhattacharya B. (2006). Effect of different levels of nitrogen and different spacing on growth and yield of cabbage. Environmental Ecology, 14(2): 504-306.

Marc, C., Abebe Shimelis, and Mitiku Haylu. (2000). Farmers' Knowledge of Soil Fertility and Local Management Strategies in Tigray, Managing Africa's Soils. Tigray, Ethiopia, 25-39.

Mbatha, A.L. (2008). Thesis on Influence of Organic Fertilizers on the Yield and Quality of Cabbage and Carrot; Faculty of Natural and Agricultural Sciences Department of Soil, Crop and Climate Sciences; University of the Free State; Bloemfontein, pp: 76-94.

MoA. (2002). Ministry of Agriculture. Agricultural Production Statistics for the Year 2002. Addis Ababa Ethiopia.

MoA. (2011). Animal and Plant Health Regulatory Directorate. Crop Variety Register: ISSUE No 14. Pp: $182-$ 188.

Moamogwe, M. (2005). Adaptation Trial of Introduced Cabbage Cultivars. ARP Training Reports (1995-1997) AVRDC-AFRICA Regional Program, Arusha, Tanzania. Pp:27- 29.

Murwira, H.K. and Kirchman, A.K. (2007). Carbon and nitrogen mineralization of cattle manures subjected to different treatment in Zimbabwean and Swedish soils: In Mulongoy K and Merckr KR (editors) Soil organic matter dynamics and sustainability of tropical agriculture, Pp:189-198.

Nkoa, R.J., Coulombe, Y., Desjardins, J., Owen and Tremblay, N. (2002). Nitrogen supply phasing increases broccoli (Brassica oleraceae var italica) growth and yield Acta-Horticulture, 571: 163-170.

Olaniyi, J.O. and Ojetayo, A.E. (2011). Effect of fertilizer types on the growth and yield of two cabbage varieties. Journal of Animal and Plant Sciences, 12 (2): 573-582.

Olsen, S.R., Cole, C.V., Watanase and Dean L.A. (1954). Estimation of Available phosphorus in soils by extraction with Sodium Bicarbonate. USA Circular No 939:1- 19.USDA, Warl.

Omori, S., Sugimota, M. and Ogura. (2002). Studies on the utilization of large quantities on animal manure for horticultural crops. Experiments on the application of fresh manure to vegetable crops. Karagawa Horticultural Experimental Staistics, 20: 58-66.

Palm, C.A., Myers, P.J.K.R and Nandwa, S.M. (1997). Combined use of organic and inorganic nutrient sources for soil fertility maintenance and replenishment. In: Buresh et al.(eds.). Replenishing soil fertility in Africa. American Society of Agronomy, 51:193 - 217. 
Pant, T., Narendra, K. and Kumar, N. (2006). Response of different doses of nitrogen on the yield of cabbage. New Agriculturist, 7(1): 21-24.

Parmar, H.C., Aliwal, G.L., Kaswala, R.R. and Patel, M.L. (2009). Effect of irrigation, nitrogen and spacing on yield of cabbage. Indian Journal of Horticulture, 56:3. Pp: 256- 258.

Peck, N.H. (1998). Cabbage plant responses to nitrogen fertilization. Agronomy Journal, 73:679-684

Pierce, L.C. (2007). Vegetables: Characteristics, Production and Marketing. John Wely and Sons, Inc. Toronto, Canada.

Preece, J.E. and Read, P.E. (2005). The biology of horticulture: An introductory textbook. $2^{\text {nd }}$ Edition. John Wiley and Sons, Inc. Hoboken, New Jersey.

Rincon, L., Pellicer, C., and Saez, J. (1998). Effect of different nitrogen application rates on yield and nitrate concentration in lettuce crops. Agrochemical 42, 304-312.

Roe, E.N. and Cornforth, C.G. (2000). Effect of dairy lot scraping and composted dairy manure on growth, yield and profit potential of double-cropped vegetables. Compost Sci. and Utilization, 8: 320-7.

Rosen, C.J. And Eliason, R. (2005). Nutrient Management for Commercial Fruit and Vegetable Crops in Minnesota. University of Minnesota Extension Service. Publication BU- 05886.

Ryan, J., Estefan, G. and Rashid, A. (1965). Soil and Plant Analysis Laboratory Manual. $2^{\text {nd }}$ Edition. Jointly published by the International Center for Agricultural Research in the Dry Areas (ICARDA) and the National Agricultural Research Center (NARC).Available from ICARDA, Aleppo, Syria 172p.

Samant, P.K.S., Sasu, S.K. and Singh, D.N. (2003). Studies on balanced fertilizer use for cabbage in acid clay loam soils of Orissa. Orissa Journal of Agricultural Research Station, 5:45-49.

Sanderson, K.R. and Ivany, J.A. (1999). Cole Crop Yield Response to Reduced Nitrogen Rates. Canadian Journal of Plant Science, 79, 149-151.

Sarker, M.J.U., Anwar, M.N., Chowdhury, M.M.U., Hoque, A.K.M.S. and Islam, M.S. (1996). Effects of organic manure and lime on cabbage in hill soils of Chittagong. Bangladesh Horticulture, 24:129-134.

Sarker, M. J.U., Begum, F., Hasan, M. K., Raquibullah, S. M. and Kader, M. A. (2003). Effect of Different Sources of Nutrients and Mulching on Growth and Yield Contributing of Cabbage. Asian Journal of Plant Sciences, 2:175-179.

Saxsena, G.K., Locascio, S.J. and Lucas, J.B. (2005). Effect of NPK rates on response on cabbage and tomato on a coastal clay soil of Guyana. Tropical Agricultural, 52 (2): 149-156.

Sisay Hailu, Tilahun Seyoum and Nigussie Dechassa. (2008). Effect of Combined Application of Organic P and Inorganic N Fertilizers on Yield of Carrot. African Journal of Biotechnology, 7(1):27-34.

Smith, K. (1995). Keith Smith's classic vegetable catalogue. Thomas C. Lothian Private Limited Company. Melbourne, Australia.

Sorensen, J.N. (2003). Improved N efficiency in vegetable production by fertilizer placement and irrigation. Acta Horticulture, 428:131-140.

Stamatiadis, S., Werner M. and Buchanan M. (2009). Field assessment of soil quality as affected by compost and fertilizer application in a broccoli field (San Benito County, California). Applied Soil Ecology, 12: 217-25.

Subhan. (2008). Effect of organic materials on growth and production of cabbage (Brassica oleraceae L.) Bulletin. Peletitian Hortikultura, 16(4): 37-41.

Tei, F., Benincasa, P., Guiducci, M. (2000). Effect of nitrogen availability on growth and nitrogen uptake in lettuce. Acta Horticulturae, 533:385-392.

Tekalign Mamo, Haque, I. and Aduayi, E.A. (1991). Soil, plant, water, fertilizer, animal manure and compost analysis manual. Plant science division working document 13, ILCA, Addis Ababa, Ethiopia.

Vachhani, M.U. and Patel, Z.G. (1991). Bulb yield quality of onion as influenced by levels of nitrogen, phosphorus and potash under south Gujrat condition. Progressive Horticulture, 23:55-56.

Van Reeuwijk, L.P. (1992). Procedure for soil analysis. $2^{\text {nd }}$ edition, International Soil Reference and Information Center (ISRIC), the Netherlands.371Pp.

Vimala, P., Illias, M.K. and Salbiah. (2006). Effect of rates of organic fertilizer on yield growth, yield and nutrient content of cabbage (Brassica oleracea var.capitata) grown under shelter. Acta Horticulture, 710:391-397.

Wakene, N., Kafyalew, N., Friesen, D.K., Ransom, J. and Yadessa, A. (2001). Determination of Optimum Farmyard Manure and NP Fertilizers for Maize on Farmer's Field. $7^{\text {th }}$ Eastern South Africa Regional Maize Conference. Pp:387-393.

Walkley, A. and Black, C.A. (1934). An examination of different methods for determining soil organic matter and the proposed modification by the chromic acid titration method. Soil Sciences, 37: 29-38.

White, J.M. and Forbes, R.B. (2007). Effect of spacing and fertilizer rotes on cabbage yield and head weight. Proceeding of the Florida State Horticulture Science, 89:118-120.

Wong, J.W.C., Ma, Fang, K.M. and Cheung, C. (1999). Utilization of manure compost for organic farming in Hong Kong. Bio-resource Technology, 67: 43-6. 
World Bank. (1998). Rwanda Poverty Note, Rebuilding an Equitable Society: Poverty and Poverty Reduction after the Genocide. Pp:3-5.

Yamaguchi, M. (2003). World Vegetables. The AVI Publishing Company, Inc. USA.245p.

Yano, M., Ito, H., Hayami, A. and Obama, S., (1999). Effect of cultural practices on the quality of vegetables. Sugar contents of cabbage and carrot. Bulletin of National Institution of Vegetable and Tea Science, Pp: 53-67.

Yazachew Etefa and Kasahun Dibaba, (2011). Physical and Socio Economic Profile of Guji Zone Districts'. Bureau of Finance and Economic Development: Regional Data and Information Core Process. Pp:7-11.

Ye, J.W., Yan, C., Ling, S.L., Ming, Z.X., Chen, Z.G. and Yao, S.S. (2004). Effect of the combined application of organic manure and fertilizer on Chinese cabbage yield and quantity Jilin Agricultural University, 26:155-157.

Appendix Table 1.Linear Correlation Coefficient (r) for Yield and Yield Components of Head Cabbage

\begin{tabular}{|c|c|c|c|c|c|c|c|c|c|c|c|c|}
\hline & $\mathrm{T}$ & $\mathrm{R}$ & PH & NELVS & $\mathrm{HH}$ & $\mathrm{HD}$ & HWUTR & HWTR & YLDRPR & YLDWRPR & BMY & HI \\
\hline $\mathrm{T}$ & 1.000 & $0.000^{\mathrm{ns}}$ & $0.762 * * *$ & $0.559 * * *$ & $0.207^{\mathrm{ns}}$ & $0.346^{*}$ & $0.367 * *$ & $0.074^{\mathrm{ns}}$ & $0.748 * * *$ & $0.742 * * *$ & $0.748 * * *$ & $0.252^{\mathrm{ns}}$ \\
\hline $\mathrm{R}$ & & 1.000 & $0.452 * *$ & $0.602 * * *$ & $0.339 *$ & $0.287 *$ & $0.161^{\text {ns }}$ & $0.211^{\mathrm{ns}}$ & $0.318^{*}$ & $0.259 *$ & $0.318^{*}$ & $-.032^{\mathrm{ns}}$ \\
\hline $\mathrm{PH}$ & & & 1.000 & $0.835 * * *$ & $0.371 * *$ & $0.429 * * *$ & $0.410 * *$ & $0.271 \mathrm{~ns}$ & $0.776 * * *$ & $0.712 * * *$ & $0.776 * * *$ & $0.098 \mathrm{~ns}$ \\
\hline NELVS & & & & 1.000 & $0.378 * *$ & $0.327 \mathrm{~ns}$ & $0.351 *$ & $0.307 \mathrm{~ns}$ & $0.699 * * *$ & $0.648 * * *$ & $0.699 * * *$ & $0.113 \mathrm{~ns}$ \\
\hline $\mathrm{HH}$ & & & & & 1.000 & $0.847 * * *$ & $0.721 * * *$ & $0.732 * *$ & $0.680 * * *$ & $0.652 * * *$ & $0.680 * * *$ & $0.112 \mathrm{~ns}$ \\
\hline $\mathrm{HD}$ & & & & & & 1.000 & $0.743^{*}$ & $0.671^{* *}$ & $0.706 * * *$ & $0.687 * * *$ & $0.707 * * *$ & $0.135 \mathrm{~ns}$ \\
\hline HWUTR & & & & & & & 1.000 & $0.903 * *$ & $0.751 * * *$ & $0.764 * * *$ & $0.751 * * *$ & $0.303 *$ \\
\hline HWTR & & & & & & & & 1.000 & $0.602 * * *$ & $0.618 * * *$ & $0.602 * * *$ & $0.268^{*}$ \\
\hline YLDRPR & & & & & & & & & 1.000 & $0.963 * * *$ & $1.000 * * *$ & $0.227 * *$ \\
\hline YLDWUT & & & & & & & & & & 1.000 & $0.963 * * *$ & $0.466 * *$ \\
\hline BMY & & & & & & & & & & & 1.000 & $0.228 \mathrm{~ns}$ \\
\hline HI & & & & & & & & & & & & 1.000 \\
\hline
\end{tabular}

Where $\mathrm{T}=$ Nitrogen, $\mathrm{R}=$ Farmyard manure, $\mathrm{PH}=\mathrm{Plant}$ height, NELVS $=$ Number of expanded leafs, =Days to maturity, $\mathrm{HH}=$ Head height, $\mathrm{HD}=$ Head diameter, HWUTR=Head weight untrimmed, HWTR=Head weight trimmed, YLDRPR=Yield with wrapper, YLDWRPR=Yield without wrapper, BMY=Biomass yield, $\mathrm{HI}=$ Harvest index, $\mathrm{ns}=$ non-significant difference, $*$ indicates significant at $5 \%$, ** indicates significant at $1 \%$, *** indicates highly significant at $1 \%$.

Appendix Table 2.Cost Benefit Analysis

\begin{tabular}{lccccr}
\hline Treatments & $\begin{array}{c}\text { Adjusted yield } \\
\left(\mathrm{t} \mathrm{ha}^{-1}\right)\end{array}$ & $\begin{array}{c}\text { Gross Benefit } \\
\left(\text { Birr ha }^{-1}\right)\end{array}$ & $\begin{array}{c}\text { Total } \\
\text { cost }\left(\text { Birr ha }^{-1}\right)\end{array}$ & $\begin{array}{c}\text { variable } \\
1\end{array}$ \\
\hline T0R0 & 17.235 & 51705 & 6570 & 45135 & 0 \\
T0R1 & 22.365 & 67095 & 8321 & 58774 & 778.9263 \\
T0R2 & 28.377 & 85131 & 9391 & 75740 & 1585.607 \\
T0R3 & 29.169 & 87507 & 10743 & 76764 & 75.73964 \\
T1R0 & 35.307 & 105921 & 12423 & 93498 & 996.0714 \\
T1R1 & 37.665 & 112995 & 14795 & 98200 & 198.2293 \\
T1R2 & 38.862 & 116586 & 16893 & 99693 & 71.16301 \\
T1R3 & 40.707 & 122121 & 18546 & 103575 & 234.8457 \\
T2R0 & 43.614 & 130842 & 20076 & 110766 & 470 \\
T2R2 & 55.422 & 192581 & 27546 & 165035 & 2083.741 \\
T2R3 & 47.731 & 198805 & 30734 & 168071 & 95.23212 \\
T3R2 & 64.224 & 213814 & 37756 & 176058 & 2535.315 \\
\hline
\end{tabular}

Where $\mathrm{T}=$ nitrogen $\mathrm{R}=$ farmyard manure, $\mathrm{t}=$ ton, ha=hectare, and $\mathrm{MRR}=$ marginal rate of returns 